\title{
Discussion Paper No. 15-086 \\ ICT and Global Sourcing - Evidence for German Manufacturing and Service Firms
}

Fabienne Rasel

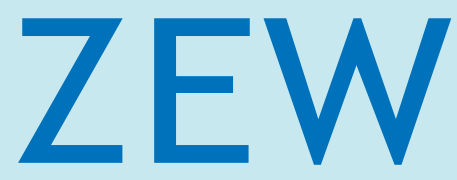

Zentrum für Europäische Wirtschaftsforschung $\mathrm{GmbH}$

Centre for European

Economic Research 


\title{
Discussion Paper No. 15-086 \\ ICT and Global Sourcing - Evidence for German Manufacturing and Service Firms
}

\author{
Fabienne Rasel
}

Download this ZEW Discussion Paper from our ftp server:

http://ftp.zew.de/pub/zew-docs/dp/dp15086.pdf

Die Discussion Papers dienen einer möglichst schnellen Verbreitung von neueren Forschungsarbeiten des ZEW. Die Beiträge liegen in alleiniger Verantwortung der Autoren und stellen nicht notwendigerweise die Meinung des ZEW dar.

Discussion Papers are intended to make results of ZEW research promptly available to other economists in order to encourage discussion and suggestions for revisions. The authors are solely responsible for the contents which do not necessarily represent the opinion of the ZEW. 


\title{
ICT and Global Sourcing - Evidence for German Manufacturing and Service Firms*
}

\author{
Fabienne Rasel ${ }^{\dagger}$ \\ ZEW Mannheim and CDSE, University of Mannheim
}

December 2015

\begin{abstract}
This paper analyses the relevance of information and communication technologies (ICT) for firms' probability of global sourcing of inputs. Using firm-level data from Germany in 2009, which include mainly small and medium-sized firms, the empirical analysis differentiates between manufacturing and service firms. The results show some differences between the manufacturing and service sector. Controlling for various sources of firm heterogeneity, the global sourcing probability is increasing in the firms' share of employees with Internet access in the manufacturing sector. E-commerceintensive firms are more likely to source inputs from abroad but generally, this relationship between e-commerce and global sourcing is only robust in services and much stronger there than in manufacturing. In both sectors, it is strongest in industries with higher upstream industry diversity. Moreover, labour productivity is positively linked to global sourcing. The findings support arguments for the importance of the Internet for global trade and they confirm the productivity advantage of importing in comparison to non-importing firms that is stated in the literature.
\end{abstract}

keywords: global sourcing, importing, information and communication technologies, inputs

JEL codes: D22, L23, F14

\footnotetext{
*I thank Irene Bertschek, Tibor Besedeš, Chris Forman, Henry Sauermann and participants at the EARIE 2013, the ETSG 2013, the IIIrd ICT Conference in Munich and seminars at ZEW, at the University of Mannheim and at Georgia Tech for helpful comments and Jakub Tezca for competent research assistance. An earlier version of this paper was published as ZEW discussion paper with the title "Offshoring and ICT - Evidence for German manufacturing and service firms". All remaining errors are mine. This paper was developed as part of Deliverable 4.3 of SERVICEGAP "International outsourcing of manufacturing and services and its effects on productivity, employment and innovation". SERVICEGAP project is funded by the European Commission, Research Directorate General as part of the 7th Framework Programme, Theme 8: Socio-Economic Sciences funded by the European Commission, Research Dir
and Humanities, Grant Agreement No. 244552.

${ }^{\dagger}$ Contact: Centre for European Economic Research (ZEW), ICT Research Department, L7, 1; 68161 Mannheim; Germany, email: rasel[at]zew.de. For further details see: http://www.zew.de/staff_frl
} 


\section{Introduction}

Recent advances in information and communication technologies (ICT) are recognised to be an important driver behind the rise in global trade in intermediate inputs. This phenomenon has led to an increased importance of global value chains. As ICT have the potential to reduce costs associated with coordination across distance, it has become easier for firms to source inputs, either goods or services, from abroad. Moreover, ICT have enabled new possibilities of splitting work tasks. For instance, Grossman and Rossi-Hansberg (2007) state, p. 59: "Revolutionary progress in communication and information technologies has enabled an historic (and ongoing) break-up of the production process." Generally, ICT can reduce communication, information and coordination costs, which in an international context, may be interpreted as trade costs. Furthermore, ICT may also indirectly affect the global sourcing decision through increased firm performance given the productivity-enhancing impact of ICT and the argument put forward by Antrás and Helpman (2004) that due to fixed costs of starting to source globally, firms need a certain productivity level to be able to engage in it (Benfratello et al. (2015)). ICT may particularly be an enabler for trade in services because many services, for instance, accounting services or technical support, have been viewed as non-tradable before. Empirical evidence supports this view by showing that the Internet can be related to growth in service trade at the macroeconomic level in the late 1990s (Freund and Weinhold (2002)).

This paper presents new evidence for the relevance of ICT and productivity for the decision to source inputs from abroad for manufacturing and service firms. Prior firm-level studies find primarily that on average more ICT-intensive firms are more likely to outsource inputs and also to import them. However, the empirical evidence for the relevance of ICT for global sourcing decisions is mainly for manufacturing firms only (e.g., Benfratello et al. (2015), Fort (2015)) or presents average effects for manufacturing and service firms together (Abramovsky and Griffith (2006)). To the best of my knowledge, there is no empirical analysis that studies explicitly global sourcing decisions of service firms and the contribution of ICT to it. Thus, it remains an open question whether ICT and other sources of firm heterogeneity, which have been identified as important factors for selection into international trade, such as productivity, have a different marginal impact for service firms' importing decisions than for manufacturing firms. In general, services are more difficult to trade. Moreover, given that prior research has found the impact of ICT on productivity to differ between manufacturing and service firms (e.g., Timmer et al. (2010), Tambe and Hitt (2012)) and empirical evidence also shows differences in the productivity sorting across technology intensity between exporters and non-exporters of these two sectors (Bertschek et al. (2015)), the contribution of ICT for global sourcing might be different between these two sectors, too. 
The goal of this paper is to provide new empirical evidence on the relationship between ICT and global sourcing and the role of productivity for global sourcing in the manufacturing as well in the service sector. In particular, the empirical analysis uses a probit model and investigates separately for manufacturing and for service firms whether the global sourcing probability increases with the use of different ICT applications, conditional on other sources of firm heterogeneity. In this paper, global sourcing is defined as importing inputs, either goods or services, and it is used interchangeably with the term importing. ${ }^{1}$ The dataset comprises information on ICT use and global sourcing activities of firms from the manufacturing and service sector in Germany from 2009. The firms are mainly small and medium-sized enterprises (SMEs), i.e. firms with at most 250 employees. Many of the service firms in the dataset are from industries that offer business-related or knowledge-intensive services, and some of them offer exactly those services that have been often named as being candidates to be offshored, such as information technology services. Firms' ICT intensity is measured by three broad types of ICT: e-commerce activities, enterprise software systems, and the diffusion of computers and Internet access within the firm.

Given the cross-sectional nature of the data, the results reflect empirical correlations between ICT use and global sourcing. To gauge the robustness of the results, I present several robustness checks. First, I consider additional sources of firm heterogeneity; second, I analyse the relevance of ICT for global sourcing for different subsamples of firms; and third, I investigate the role of ICT for firms in industries with higher versus lower upstream supply chain complexity.

The results show some differences between manufacturing and service firms. In the manufacturing sector, the probability of global sourcing is increasing in the share of employees with Internet access. In both sectors, more e-commerce-intensive firms are more likely to import inputs from abroad, in particular in industries with higher upstream supply chain complexity. However, across all industries, the association between e-commerce and global sourcing is only robust for service firms for which it is also stronger than for manufacturing firms. In quantitative terms, the use of an additional e-commerce application is associated with a 5 to 6 percentage points increase in the probability of global sourcing for service firms and with a magnitude of a 1 to 3 percentage points for manufacturing firms. Given that 20.1 percent in the service sector engage in global sourcing compared to 59.5 percent in the manufacturing sector, the economic magnitudes of the relevance of e-commerce for global sourcing in services are much larger than in manufacturing. Further results are that more

\footnotetext{
${ }^{1}$ The role of ICT for sourcing inputs from a foreign firm has often been discussed in the offshoring context. A standard definition of offshoring in the literature is "the relocation of jobs and processes to any foreign country without distinguishing whether the provider is external or affiliated with the firm" (Olsen (2006), p. 6). The inputs produced at the foreign location are then imported, i.e. offshored. Global sourcing of inputs might include firms' offshoring activities. Since the data in this paper cannot distinguish between the importing of inputs that previously have been produced at the firm and importing of inputs that have always been sourced from abroad, this paper uses the term global sourcing or importing instead of offshoring. See also Section 3.
} 
productive manufacturing as well as service firms are more likely to import inputs. Equally, this relationship is found mainly in industries with higher upstream supply chain diversity.

The empirical study contributes to the literature in three respects. First, the paper extends the knowledge about the relevance of ICT for outsourcing and global sourcing. In contrast to the prior empirical evidence which mostly considers one or two measures for firms' ICT use, for instance, ICT investment or Internet ordering (Abramovsky and Griffith (2006)), or electronic networks (Fort (2015)), this paper analyses the role of various ICT measures in their relationship to global sourcing. The different measures account for the heterogeneity of ICT and allow to distinguish which kind of ICT might be relevant for firms' global sourcing activities. In particular, to the best of my knowledge, the analysis provides first firm-level evidence on the relationship between enterprise software systems use and global sourcing. Moreover, it provides first empirical evidence about the role of ICT for the probability of global sourcing for service firms since prior studies analyse only the impact of service sourcing on the decision to outsource or offshore (Abramovsky and Griffith (2006)) or the effects of service importing on productivity (e.g., Amiti and Wei (2009), Görg et al. (2008)). The distinction between the manufacturing and service sector allows to investigate similarities and potential differences between the two sectors with respect to the link between importing, ICT use and other firm characteristics.

Second, related to the relevance of technology for global sourcing is the literature on the role of technology for international trade. The existing literature has mainly focused on the export margin (e.g., Lileeva and Trefler (2010), Bustos (2011)) and usually finds that manufacturing firms that are active on international markets use more advanced technology. However, for service firms empirical evidence has shown that the group of non-exporting firms that use advanced technology may be large, too (Bertschek et al. (2015)). This paper adds empirical evidence about the ICT intensity of importing firms in comparison to nonimporting firms.

Third, the analysis contributes to the literature on international trade in services by showing evidence for service as well as for manufacturing firms. Existing scarce empirical evidence shows many similarities between service and goods trade at the firm level and concludes that heterogeneous firm models of international trade developed for goods trade may be also a good starting point for studying service trade (Breinlich and Criscuolo (2011)). This paper allows examining whether heterogeneous firm models for the importing decision are supported by the data for manufacturing as well as for service firms.

The remaining paper is structured as follows: Section 2 discusses the relevant literature for the empirical analysis. Section 3 describes the data and explains the measurement of the central variables followed by the presentation of the econometric implementation. In section 4 the empirical results are presented and discussed, and section 5 concludes. 


\section{Literature and background discussion}

Arguments and empirical evidence from various literature strands are relevant for the analysis of this paper. There is the literature on the benefits of ICT for outsourcing, domestic or international, and offshoring of inputs that stresses how ICT have changed the costs of outsourcing. The worldwide diffusion of the Internet has reduced communication costs across distance. In general, networked ICT can lower the costs of coordinating economic activity inside the firm and with outside market participants (Forman and McElheran (2015)). ICT help reducing the costs of outsourcing of business services as they have the potential to lower search and transaction costs directly and as they can decrease the degree of specificity of the transaction since ICT are compatible with general skills, which are easily transferrable across firms (Abramovsky and Griffith (2006)): Therefore, firms with a higher ICT investment level are expected to outsource and offshore more services. ICT also enable a change in the task composition of jobs (Autor et al. (2003)), thereby facilitating the fragmentation of production processes across space and consequently, also across borders. The ICT-facilitated fragmentation of production facilitates so-called "trade in tasks", a term suggested by Grossman and Rossi-Hansberg (2008) that highlights the labour content of offshoring manufacturing tasks and business functions. Moreover, ICT may improve the matching of buyers and suppliers of specialized inputs and business services through electronic markets, which may increase outsourcing activities (Grossman and Helpman (2002)).

The principal reason for sourcing inputs from abroad is seen in exploiting labour cost differences across countries. Therefore, in theoretical models of global sourcing, wage differences across countries are central elements that determine the decision to source globally (e.g., Antrás and Helpman (2004), Grossman and Rossi-Hansberg (2008)). Another reason is the possibility to source new inputs, potentially not available domestically or of better quality (Amiti and Konings (2007)).

Besides the ICT-enabled direct cost reduction of communication and of coordination problems and the ICT-facilitated change in the job task composition as drivers for outsourcing inputs, ICT may also indirectly affect a firm's global sourcing decision through ICT-improved firm performance (Benfratello et al. (2015)). The argumentation for the indirect effect of ICT on the offshoring decision is based on two strands of the literature: On the one hand, by now it is undisputed that ICT may be productivity-enhancing. There is a large literature on the productivity effects of ICT investment. ${ }^{2}$ On the other hand, firm heterogeneity in productivity is suggested to be an important determinant for a firm's global sourcing decision: More productive firms are more likely to engage in global sourcing as they have the resources to overcome the fixed costs of sourcing from abroad (Antrás and Helpman (2004)). The fixed (sunk) costs of global sourcing include, for instance, searching for foreign suppliers or making contracts. This theoretical consideration suggests a causal self-selection of already

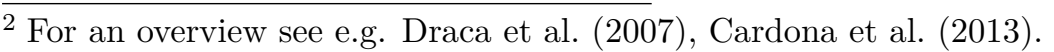


more productive firms into global sourcing prior to starting to source inputs from abroad. Self-selection into entry in international markets based on productivity differences is at the centre of heterogeneous firm models in trade. While the literature has primarily focused on exporting, ${ }^{3}$ there are also theories of importing that model fixed costs of sourcing from abroad (e.g., Antrás and Helpman (2004), Antras et al. (2014)). ${ }^{4}$

Empirical evidence supports self-selection into importing based on productivity (e.g., Wagner (2011) for offshoring firms and Vogel and Wagner (2010) for importing firms from Germany) and stresses the role of fixed costs of global sourcing (e.g., Fort (2015), Antras et al. (2014)). Importing firms tend to differ systematically from non-importing firms in other dimensions than productivity, too. Similar to the performance advantage of exporters in comparison to non-exporters, ${ }^{5}$ global sourcing firms are larger and pay higher wages (e.g., Wagner (2011) for German offshoring firms, Ariu (2015) for Belgium importers). Moreover, Bernard et al. (2007) find that U.S. importing manufacturers have mainly very similar characteristics to exporting firms and that this similarity can be mainly attributed to the fact that importing firms are often at the same time exporters, too: They are larger, more productive, more capital- and skill-intensive, pay higher wages prior to international market entry than nonexporting and non-importing firms. Furthermore, empirical evidence finds also positive productivity effects from importing of inputs (e.g., for goods importing, Amiti and Konings (2007), Halpern et al. (2015); for service offshoring, e.g., Görg et al. (2008)).

Prior firm-level evidence for the relationship between ICT use and global sourcing activity supports a positive correlation: A higher computer intensity is linked with a higher foreign outsourcing intensity for Japanese manufacturers (Tomiura (2005)). Using firm-level data from the United Kingdom, Abramovsky and Griffith (2006) find that firms with higher investments in ICT and using the Internet to order goods or services outsource more business services and are more likely to offshore them, too. For Korean manufacturers, an ICT level of at least using the Internet for e-commerce is positively related to the offshoring decision, in particular for offshoring from the own foreign affiliate (Hyun (2010)). Two firm-level studies for the U.S. and for Italy present more mixed results for the effect of ICT on global sourcing: For U.S. manufacturers, Fort (2015) finds that the use of electronic communication networks has a positive significant effect on production fragmentation and consequently on sourcing from an external supplier. However, this effect of communication technology on sourcing activities is disproportionately larger for domestic than for foreign sourcing, which is argued to be compatible with complementarity between technology and worker skill. ${ }^{6}$ For Italian

\footnotetext{
3 The model of Melitz (2003) is seen as the baseline model for the relevance of firm heterogeneity in export decisions. See Redding (2011) for a review of theories of heterogeneous firms.

${ }^{4}$ See Antras et al. (2014) also for a brief literature review of models of global sourcing and offshoring.

${ }^{5}$ See e.g. Bernard et al. (2012) for a survey.

6 To support this view, Fort (2015) shows that the effect of communication technology on global sourcing is increasing in the sourcing country's human capital with increasing IT intensity of the production processes. This is interpreted as evidence that firms look for sourcing partners that are technologically advanced enough to cope with the technology requirements.
} 
manufacturers, Benfratello et al. (2015) show that ICT have a negative effect on offshoring, where the effect is only significant for low-tech firms leading the authors to conclude that ICT may substitute for routine tasks domestically, which are then performed by foreign workers. All these firm-level studies analyse the role of ICT for manufacturing firms' global sourcing decisions and to the best of my knowledge, there is no analysis that studies explicitly also the relevance of ICT for global sourcing activities of service firms.

However, there is some empirical evidence about firms that trade services. Breinlich and Criscuolo (2011) provide characteristics of UK exporters and importers that trade services. They find that only very few firms trade services and, similar to previous evidence for firms trading goods, that service importers are larger in terms of employment and sales, more labour productive, more capital intensive, they pay higher wages and are more likely to be foreign-owned or part of a multinational. The German Central Bank (Deutsche Bundesbank) collects data on international trade in services for the computation of the German Balance of Payments Statistics (Biewen et al. (2013)). Similar to the firm heterogeneity in international services trade for UK firms documented by Breinlich and Criscuolo (2011), the data reflect that many firms import only a very small share, two-way traders ${ }^{7}$ import more than exclusive importers, and the majority of firms imports only one service type and mostly only from one country. ${ }^{8}$ Ariu (2015) compares firms that trade goods and/or services based on trade transaction data from Belgium. The author finds that service trading firms are fewer and export and import smaller values than goods trading firms. Moreover, some empirical studies examine the impact of material and service offshoring on productivity (e.g. Amiti and Wei (2009), Görg et al. (2008)).

The goal of this paper is to provide new empirical evidence on the role of ICT for the probability of sourcing inputs globally, distinguishing between manufacturing and service firms. Based on the arguments for the impact of ICT for the global sourcing decision as derived in the literature, in general, I expect a positive association between ICT and global sourcing.

\section{Data and econometric model}

The data used for the empirical analysis are from the ZEW ICT survey 2010 conducted by the Centre for European Economic Research (ZEW). The ZEW ICT survey is collected by computer-aided telephone interviews and was also conducted in 2000, 2002, 2004, 2007 and 2014. Many questions are asked in every wave and the rotating panel format allows to build a panel dataset. However, the global sourcing variable was newly introduced in 2010

\footnotetext{
7 Two-way traders are firms that export and import.

${ }^{8}$ A more detailed analysis of firm-level characteristics for services trade by German firms based on this Bundesbank data is provided by Kelle and Kleinert (2010).
} 
so that no panel analysis can be conducted for the purpose of this paper. ${ }^{9}$ The survey has a focus on the diffusion and use of ICT. Besides the questions related to ICT, the survey provides information about general firm characteristics and performance measures such as the number of employees, the qualification structure of the labour force, total turnover and innovation activity. The survey comprises firms from the manufacturing and from the service sector with at least five employees. Around 4,400 firms located in Germany, stratified on a sectoral, size class and locational basis (East/West Germany) were interviewed. ${ }^{10}$

In order to exclude extreme outliers from the estimation sample, observations with a labour productivity below the 1 st and above the 99th percentile are dropped. ${ }^{11}$ Moreover, the sample is constructed based on the regression specification that includes the main set of control variables, which will be presented below. The resulting sample comprises 1243 firms from the manufacturing sector and 894 from the service sector. The manufacturing sector comprises seven broad industries and the service sector eight industries, among them mainly knowledge-intensive service providers.

Table 7 in the Appendix shows the distribution of firms across industries for the sample that is used in the empirical analysis as well as for the complete dataset that includes all firms that were interviewed in the 2010 wave for these industries. Since the distribution of the estimation sample is not significantly different from the complete dataset, it can be assumed that the used sample is representative with respect to the industries.

\subsection{Measuring global sourcing, ICT and further variables}

The dependent variable is a dummy variable for a firm's global sourcing behaviour that indicates whether the firm imported any inputs, goods or services, in 2009. This binary variable is constructed from the question "Based on all inputs: What is the share that was sourced from abroad in 2009?", which was only asked to firms if they imported any goods or services at all. The dummy variable is equal to one if the firm has a strictly nonzero global sourcing share, and equal to zero if the firm does not import any goods or services. The data do not allow to distinguish whether firms import goods or services. Hence, it can be just one type or both. Evidence for Belgium firms shows that firms that trade goods, i.e. export and/or import, are the majority in the manufacturing as well as in the service sector, services are mostly traded in the service sector, whereas the shares of exporters or importers of firms trading both, goods and services, are fairly similar across the manufacturing and service sector (Ariu (2015)). The information that the firm sources inputs from abroad allows to conclude that the firm makes use of inputs produced abroad for the own value

\footnotetext{
${ }^{9}$ The 2014 data are not suited either because the majority of the ICT variables considered in this paper was not asked in the 2014 survey.

${ }^{10}$ The dataset used for this analysis is accessible at the ZEW Research Data Centre: http://kooperationen.zew.de/en/zew-fdz/home.html

${ }^{11}$ In total, 51 observations are dropped, 25 which are below the 1 st and 26 which are above the 99 th percentile.
} 
creation process and that it has business contacts with foreign suppliers. The data do not include information whether the input is sourced from a foreign affiliate, which would be intra-firm trade, or from a foreign external supplier, which would refer to international outsourcing. Thus, the exact ownership of the foreign firm, from which a firm sources, remains unspecific. However, for all firms without a foreign affiliate it can be concluded that if they source inputs from abroad, they engage in international outsourcing and trade across firm boundaries. In order to check whether there is a difference in the relationship between ICT use and global sourcing for purely internationally outsourcing firms and the whole sample of firms comprising also those with a foreign affiliate, in the robustness checks the empirical analysis is conducted exclusively for firms without any foreign location.

Table 1 shows global sourcing participation in percent across industries. Around 59.5 percent of manufacturers import inputs, while global sourcing is still less frequent for service firms with only 20.1 percent. A similar pattern of trade participation is found for Belgian firms where export and import participation is higher in the manufacturing sector than in the service sector (Ariu (2015)). Across sectors in the manufacturing industry, global sourcing participation is for all except for the metal industry above 50 percent indicating that many manufacturers participate in global value chains. For the service sector, the global sourcing participation distribution looks differently. Global sourcing activities are highest in the sectors media services (31 percent) and IT and other information services (31 percent), whereas in the real estate activities sector only 7 percent import inputs. These average participation shares are consistent with the view that in general, service delivery is often relatively local and that services are more difficult to trade than manufacturing goods.

Table 1: Average global sourcing participation across industries

\begin{tabular}{|c|c|c|c|}
\hline $\begin{array}{l}\text { Manufacturing sector } \\
(\mathrm{N}=1243)\end{array}$ & $\begin{array}{l}\text { Global sourcing } \\
\text { participation in \% }\end{array}$ & $\begin{array}{l}\text { Service sector } \\
(\mathrm{N}=894)\end{array}$ & $\begin{array}{l}\text { Global sourcing } \\
\text { participation in \% }\end{array}$ \\
\hline Consumer goods & 53.70 & Transportation & 19.55 \\
\hline Chemical and pharmaceutical industry & 70.19 & Media services & 30.69 \\
\hline Other raw materials & 62.57 & IT and other information services & 30.77 \\
\hline Metal industry & 47.62 & Financial and insurance activities & 8.25 \\
\hline Electrical engineering & 71.65 & Real estate activities & 7.41 \\
\hline Machine construction & 54.95 & Business consultancy and advertising & 15.79 \\
\hline \multirow[t]{2}{*}{ Vehicle construction } & 66.30 & Technical services & 22.54 \\
\hline & & Other business services & 13.68 \\
\hline Total & 59.45 & Total & 20.13 \\
\hline
\end{tabular}

Data source: ZEW ICT survey 2010.

The main variable of interest is a firm's ICT intensity. Instead of measuring it with one variable, in the main analysis ICT intensity is captured by various ICT applications, which can be categorized into three broad types of ICT. First, an electronic commerce (e-commerce) count indicator is constructed based on three questions in the survey about the use of the Internet for ordering products or services from suppliers (question 1), and for selling goods or services, either to private end-consumers, i.e. business-to-consumer (B2C) e-commerce (question 2), or to companies, i.e. business-to-business (B2B) e-commerce (question 3). Internet ordering is a form of electronic buying (e-buying) and B2C and B2B e-commerce can be viewed as forms of electronic selling (e-selling). In this paper, the term e-commerce 
is used to summarize e-buying and e-selling activities. These e-commerce uses are Internetenabled business process innovations that may have changed on the one hand, the possibilities how to interact with suppliers and customers, and on the other hand, the costs of interaction. The three e-commerce uses are aggregated into an e-commerce indicator that ranges from zero for no use to three for the use of all of the e-commerce possibilities. The indicator can be interpreted as a proxy for the intensity of the use of Internet-based communication and coordination with suppliers and customers. The aggregation of the three e-commerce options into a count variable also aims at minimizing multicollinearity in the regression because all variables are correlated with each other as it is shown in Table 2.

The majority of firms in the manufacturing (50 percent) and service (43 percent) sector uses only one form of e-commerce followed by two forms (Table 2). Moreover, if they use e-commerce, mostly they use Internet ordering plus possibly B2B or B2C e-commerce. In the manufacturing sector, 78 percent use Internet ordering from suppliers, 34 percent offer B2B e-commerce and 16 percent $\mathrm{B} 2 \mathrm{C}$ e-commerce. In the service sector, the average adoption values are slightly higher with 81 percent for Internet ordering, 39 percent for B2B and 22 percent for $\mathrm{B} 2 \mathrm{C}$ e-commerce. This diffusion distribution is consistent with the fact that e-selling usually involves more complex organizational changes and higher adjustment costs than e-buying (McElheran (2015)). Given these different adoption costs of e-buying and e-selling, instead of the e-commerce count indicator, in the empirical analysis I also consider the individual e-commerce measures separately in how they are related to global sourcing.

Table 2: Descriptive statistics of e-commerce use

\begin{tabular}{|c|c|c|c|c|c|c|c|c|c|}
\hline \multirow[b]{2}{*}{ no. e-commerce applications } & \multicolumn{9}{|c|}{ Manufacturing sector $(\mathrm{N}=1243)$} \\
\hline & 0 & 1 & 2 & 3 & & & & & \\
\hline & \multicolumn{4}{|c|}{ Frequency distributions in $\%$} & Mean & SD & Median & Min & $\operatorname{Max}$ \\
\hline \multirow[t]{3}{*}{ E-commerce indicator } & 15.85 & 50.12 & 24.70 & 9.33 & 1.28 & 0.84 & 1 & 0 & 3 \\
\hline & \multicolumn{4}{|c|}{ Correlations } & & & & & \\
\hline & Internet o. & $\mathrm{B} 2 \mathrm{~B}$ & $\mathrm{~B} 2 \mathrm{C}$ & - & & & & & \\
\hline Internet ordering & 1 & & & & 0.78 & 0.42 & 1 & 0 & 1 \\
\hline B2B e-commerce & 0.10 & 1 & & & 0.34 & 0.48 & 0 & 0 & 1 \\
\hline \multirow[t]{2}{*}{$\mathrm{B} 2 \mathrm{C}$ e-commerce } & 0.10 & 0.30 & 1 & & 0.16 & 0.36 & 0 & 0 & 1 \\
\hline & \multicolumn{9}{|c|}{ Service sector $(\mathrm{N}=894)$} \\
\hline \multirow[t]{2}{*}{ no. e-commerce applications } & 0 & 1 & 2 & 3 & & & & & \\
\hline & \multicolumn{4}{|c|}{ Frequency distributions in $\%$} & Mean & $\mathrm{SD}$ & Median & Min & $\operatorname{Max}$ \\
\hline \multirow[t]{3}{*}{ E-commerce indicator } & 14.43 & 43.40 & 27.52 & 14.65 & 1.42 & 0.91 & 1 & 0 & 3 \\
\hline & \multicolumn{4}{|c|}{ Correlations } & & & & & \\
\hline & Internet o. & $\mathrm{B} 2 \mathrm{~B}$ & $\mathrm{~B} 2 \mathrm{C}$ & - & & & & & \\
\hline Internet ordering & 1 & & & & 0.81 & 0.39 & 1 & 0 & 1 \\
\hline B2B e-commerce & 0.24 & 1 & & & 0.39 & 0.49 & 0 & 0 & 1 \\
\hline $\mathrm{B} 2 \mathrm{C}$ e-commerce & 0.10 & 0.34 & 1 & & 0.22 & 0.42 & 0 & 0 & 1 \\
\hline
\end{tabular}

Data Source: ZEW ICT Survey 2010. SD stands for standard deviation; this abbreviation is also used in the subsequent tables. 
Second, four enterprise software systems are considered to reflect a different type of ICT use that focuses on software-enabled information organization: Enterprise Resource Planning (ERP), Content or Document Management systems (CDMS), Supply Chain Management (SCM) and Customer Relationship Management (CRM). ERP is a general purpose software that supports internal information management. It integrates enterprise functions such as sales and distribution, materials management, production planning, financial accounting, cost control, and human resource management (Aral et al. (2006)). CDMS software supports the management of electronic documents as well as it might include functionalities for collaboration with electronic documents. While CRM software focuses on the interaction with customers, SCM software supports ICT-based processing of the different steps of the value chain. The benefits of SCM software might be especially useful for firms with external suppliers.

The principal role of such software solutions is to assist the firm to gather information from various business processes, analyse this information and then to execute on it to increase the performance of the supply chain (Chopra and Meindl (2007)). Even though, these software systems focus on different information flows from inside or outside the firm, they have in common that they reduce information and coordination costs, which ultimately may have changed how firms organize their internal work flows as well as their external relationships. ${ }^{12}$

Table 3: Descriptive statistics of enterprise software use

\begin{tabular}{|c|c|c|c|c|c|c|c|c|c|c|}
\hline \multirow[b]{2}{*}{ no. software systems } & \multicolumn{10}{|c|}{ Manufacturing sector $(\mathrm{N}=1243)$} \\
\hline & 0 & 1 & 2 & 3 & 4 & & & & & \\
\hline & \multicolumn{5}{|c|}{ Frequency distributions in $\%$} & Mean & $\mathrm{SD}$ & Median & Min & $\operatorname{Max}$ \\
\hline \multirow[t]{3}{*}{ Software indicator } & 15.12 & 22.61 & 23.65 & 19.31 & 19.31 & 2.05 & 1.34 & 2 & 0 & 4 \\
\hline & \multicolumn{5}{|c|}{ Correlations } & & & & & \\
\hline & ERP & CDMS & $\mathrm{SCM}$ & CRM & - & & & & & \\
\hline ERP & 1 & & & & & 0.79 & 0.41 & 1 & 0 & 1 \\
\hline CDMS & 0.26 & 1 & & & & 0.47 & 0.50 & 0 & 0 & 1 \\
\hline SCM & 0.33 & 0.35 & 1 & & & 0.42 & 0.49 & 0 & 0 & 1 \\
\hline \multirow[t]{2}{*}{ CRM } & 0.30 & 0.34 & 0.43 & 1 & & 0.38 & 0.48 & 0 & 0 & 1 \\
\hline & \multicolumn{10}{|c|}{ Service sector $(\mathrm{N}=894)$} \\
\hline \multirow[t]{2}{*}{ Use intensity } & 0 & 1 & 2 & 3 & 4 & & & & & \\
\hline & \multicolumn{5}{|c|}{ Frequency distributions in $\%$} & Mean & SD & Median & Min & $\operatorname{Max}$ \\
\hline \multirow[t]{3}{*}{ Software indicator } & 14.77 & 22.48 & 22.26 & 26.85 & 13.65 & 2.02 & 1.28 & 2 & 0 & 4 \\
\hline & \multicolumn{5}{|c|}{ Correlations } & & & & & \\
\hline & ERP & CDMS & $\mathrm{SCM}$ & CRM & - & & & & & \\
\hline ERP & 1 & & & & & 0.72 & 0.45 & 1 & 0 & 1 \\
\hline CDMS & 0.27 & 1 & & & & 0.58 & 0.49 & 1 & 0 & 1 \\
\hline SCM & 0.21 & 0.24 & 1 & & & 0.24 & 0.43 & 0 & 0 & 1 \\
\hline CRM & 0.29 & 0.42 & 0.28 & 1 & & 0.47 & 0.50 & 0 & 0 & 1 \\
\hline
\end{tabular}

Data Source: ZEW ICT Survey 2010.

\footnotetext{
${ }^{12}$ For more information about ERP, SCM and CRM software, see e.g. Hindricks et al. (2007), Engelstätter (2012).
} 
Table 3 shows basic descriptive statistics of these variables. Like the e-commerce variables, also these variables are all correlated with each other. To reduce multicollinearity, I aggregate them into a count variable ranging from zero for no use of any of the systems to four if all systems are used. This count indicator can be interpreted as a measure for a firm's extent of the use of IT-supported information documentation and analysis. Moreover, it reflects the degree of investment into internal IT capabilities that possibly may also affect external business partners, for instance, in the case of SCM. McElheran (2015) points out that in the 1990s the diffusion of internally-focused IT such as ERP was an important factor for the diffusion of e-commerce solutions.

On average, two of the software systems are used by manufacturing and by service firms. Moreover, in both sectors the firms are roughly evenly distributed across the five frequency possibilities by roughly one fifth in each, even though in the two border groups of zero and five, there are slightly less than one fifth than in the three middle groups. This frequency distribution reflects substantial variation in the enterprise software adoption intensity. With respect to the adoption frequencies of the individual software systems, ERP software is diffused most broadly, followed by CDMS and then either by SCM or CRM software. This diffusion distribution is consistent with the facts discussed above that ERP is a general purpose software whereas the other software systems are aimed at specific business processes and for specific purposes, which not necessarily all firms will need.

Third, two measures of computer and Internet diffusion within the firm are included that reflect the ICT use by employees. On the one hand, the share of employees working predominantly with the personal computer (PC) is considered. This measure can be interpreted as a measure for a firm's overall ICT intensity and alternatively for labour heterogeneity (Bertschek and Meyer (2009)). It measures part of a firm's hardware and software equipment as well as it reflects the extent of the firm's use of the computer as a working tool within its business model. On the other hand, the share of employees with Internet access serves as a proxy for the relevance of the Internet for the business activity besides being a measure for the Internet diffusion within the firm. For both measures, the average values are higher in the service than the manufacturing sector as Table 4 shows. Moreover, the share of employees with Internet access (44 percent for manufacturing firms; 77 percent for service firms) is roughly ten percentage points higher than the share of employees working predominantly at the PC (34 percent for manufacturing firms; 68 percent for service firms). The larger diffusion of computer-based work and Internet access across employees in service firms than in manufacturing firms reflects that on average business-related services rely more on computer work than manufacturing production processes for which other types of machinery are relevant, too.

In light of the importance of productivity for the global sourcing decision as documented in the literature on heterogeneous firm models in international trade and on firm importing, labour productivity is considered as another main explanatory variable. It is measured as 
Table 4: Descriptive statistics of PC and Internet diffusion

\begin{tabular}{lccccc}
\hline & \multicolumn{5}{c}{ Manufacturing sector } \\
& Mean & SD & Median & Min & Max \\
\hline \% emp. working with PC & 0.34 & 0.25 & 0.28 & 0 & 1 \\
\% emp. with Internet access & 0.44 & 0.33 & 0.30 & 0 & 1 \\
\hline \hline & Mean & SD & Median & Min & Max \\
\hline \% emp. working with PC & 0.68 & 0.36 & 0.85 & 0 & 1 \\
\% emp. with Internet access & 0.77 & 0.34 & 1 & 0 & 1 \\
\hline
\end{tabular}

Data source: ZEW ICT survey 2010.

total sales per employee. More productive firms might also have better financial capacities to afford expensive ICT systems. Furthermore, as ICT have the potential to improve productivity, more ICT-intensive firms are likely to be more productive, too.

The empirical analysis considers various other firm characteristics to control for variables that might have an impact on the global sourcing decision as well as on adopting ICT. ${ }^{13}$ Table 8 in the Appendix presents descriptive statistics of those other firm characteristics. Firm size (log. number of employees) is considered because prior empirical evidence has shown that importing firms are on average larger than non-importing firms (e.g., Bernard et al. (2007), Breinlich and Criscuolo (2011), Vogel and Wagner (2010)). Firm size is often interpreted as a measure for a firm's financial capacity to afford complex and often expensive ICT systems, where larger firms are likely to have better access to financial resources than smaller firms.

Further international participation of firms besides sourcing inputs from abroad is included by a dummy variable for exporting activities and a dummy variable for existence of a foreign location. Empirical findings show that importing firms are often exporters, multinationals or foreign owned (e.g., Bernard et al. (2007), Ariu (2015)). Moreover, firms with other foreign contacts may potentially have lower importing costs because they already know business partners abroad or foreign market conditions. Thus, they might find foreign suppliers more easily or even source from own foreign locations. Furthermore, exporters are found to be more capital intensive (e.g., Bernard et al. (2012)) and more ICT intensive (e.g., Bertschek et al. (2015)) than non-exporters and use in general more advanced technology (e.g., Bustos (2011)). Exporters are also said to face more competitive pressures than non-exporters due to their participation in foreign markets (e.g., Bertschek and Kaiser (2004)). Greater competitive pressure may increase the firm's willingness to source inputs globally in order to save costs or to get access to better quality.

\footnotetext{
${ }^{13}$ For a recent review of the evidence on ICT adoption and firm characteristics see e.g. Haller and Siedschlag (2011).
} 
Human capital composition is captured by the share of high-skilled employees. ${ }^{14}$ In the literature and discussions about offshoring, it has often been discussed that if offshoring costs decrease, especially low-skilled jobs will be relocated abroad and then those tasks and inputs performed by low-skilled workers will be imported from abroad. In the domestic offshoring firm, a relocation of low-skilled jobs abroad would imply a lower share of lowskilled and a higher share of high-skilled employees so that global sourcing activities and the share of high-skilled human capital would be positively related. Moreover, skilled human capital might be an important factor to manage the international relations, for instance, for negotiating with business partners in a foreign language. A firm's human capital composition of the labour force may also be associated with its ICT use in view of the literature on skillbiased technological change (SBTC) that argues that ICT capital complements skilled labour because ICT raise its relative productivity in comparison to unskilled labour. ${ }^{15}$

To account for the association between internationalization and innovation activities, the innovative capabilities of a firm are captured by a dummy variable for product innovation and a dummy variable for process innovation. The dummy variables are equal to one if the firm has realized a product or process innovation in the period from 2006-2009, respectively. For instance, Criscuolo et al. (2005) find that globally engaged firms (exporters or being part of a multinational) innovate more than purely domestic firms. The authors argue that the innovation advantage can be contributed to a higher number of researchers but also to a more diversified set of inputs, which is available to globally engaged firms through their contacts to suppliers, customers or foreign affiliates. Furthermore, international outsourcing might increase innovation incentives because it reduces production costs through lower prices for the inputs sourced from abroad than domestically available and thereby raises a firm's profits so that the higher profits can be used to increase the innovation rate through increased R\&D spending (Glass and Saggi (2001)). ${ }^{16}$ It might also be that more innovative firms are more likely to import because they need specific inputs that are not domestically available or because they want to save costs for inputs. The innovation variables may also be correlated with the ICT variables since ICT are said to be an enabler for innovation (Brynjolfsson and Saunders (2010)) or since more innovative firms are more open to adopt new technologies. For instance, Hollenstein and Wörter (2008) find a positive relationship between the introduction of innovations and the adoption of e-commerce.

Furthermore, two variables are included that reflect the employees' power in decision-making and flexibility of work. On the one hand, a dummy variable for having a works council is considered to control for employees' voice and coordination potential at the employee level with respect to firm-related questions. On the other hand, an indicator for decentralized

\footnotetext{
${ }^{14}$ The share of highly skilled employees includes employees with a degree from university, university of applied sciences or university of cooperative education.

${ }^{15}$ See Violante (2008) for a summary of the SBTC discussion and e.g. Draca et al. (2007) for a summary of the skill-ICT complementarity hypothesis.

${ }^{16}$ See for empirical evidence, e.g. Görg and Hanley (2011) who find a positive effect of international outsourcing of services on innovative activity using plant-level data from the Republic of Ireland.
} 
workplace organization that ranges from zero to five is included. ${ }^{17}$ Exporters and multinational plants are found to be better managed (e.g., Bloom et al. (2012)) or exporters will have more layers of management, i.e. be more decentralized, due to a larger firm size than non-exporters (Caliendo and Rossi-Hansberg (2012)). Decentralized workplace organization and human resources practices have also been documented to be complementary to ICT (e.g., Bresnahan et al. (2002), Bloom et al. (2012)).

Finally, industry dummy variables based on an industry affiliation that corresponds to the NACE two-digit industry level ${ }^{18}$ are included to capture industry-specific effects. Furthermore, a dummy variable for multi-plant association as well as a dummy variable indicating whether the firm is located in East Germany, to account for possible regional effects, are considered.

Table 5: Average ICT characteristics by global sourcing status

\begin{tabular}{|c|c|c|c|c|}
\hline \multirow[t]{2}{*}{ ICT variables } & \multicolumn{2}{|c|}{ global sourcing firms } & \multicolumn{2}{|c|}{ non-global sourcing firms } \\
\hline & \multicolumn{4}{|c|}{ Manufacturing sector $(\mathrm{N}=1243)$} \\
\hline E-commerce indicator & 1.33 & 0.84 & 1.19 & 0.84 \\
\hline Internet ordering & 0.79 & 0.41 & 0.76 & 0.43 \\
\hline B2B e-commerce & 0.39 & 0.49 & 0.28 & 0.45 \\
\hline $\mathrm{B} 2 \mathrm{C}$ e-commerce & 0.15 & 0.36 & 0.16 & 0.37 \\
\hline Software indicator & 2.32 & 1.31 & 1.65 & 1.28 \\
\hline $\mathrm{ERP}$ & 0.85 & 0.36 & 0.70 & 0.46 \\
\hline CDMS & 0.53 & 0.50 & 0.38 & 0.48 \\
\hline SCM & 0.50 & 0.50 & 0.30 & 0.46 \\
\hline CRM & 0.44 & 0.50 & 0.28 & 0.45 \\
\hline \% emp. working with PC & 0.38 & 0.25 & 0.28 & 0.24 \\
\hline \multirow[t]{2}{*}{$\%$ emp. with Internet access } & 0.49 & 0.33 & 0.37 & 0.32 \\
\hline & \multicolumn{4}{|c|}{ Service sector $(\mathrm{N}=894)$} \\
\hline E-commerce indicator & 1.73 & 0.84 & 1.35 & 0.91 \\
\hline Internet ordering & 0.92 & 0.28 & 0.78 & 0.41 \\
\hline B2B e-commerce & 0.56 & 0.50 & 0.35 & 0.48 \\
\hline B2C e-commerce & 0.26 & 0.44 & 0.22 & 0.41 \\
\hline Software indicator & 2.47 & 1.19 & 1.91 & 1.27 \\
\hline $\mathrm{ERP}$ & 0.81 & 0.39 & 0.70 & 0.46 \\
\hline CDMS & 0.68 & 0.47 & 0.56 & 0.50 \\
\hline SCM & 0.37 & 0.48 & 0.21 & 0.41 \\
\hline CRM & 0.61 & 0.49 & 0.44 & 0.50 \\
\hline \% emp. working with PC & 0.70 & 0.33 & 0.67 & 0.37 \\
\hline$\%$ emp. with Internet access & 0.81 & 0.31 & 0.76 & 0.35 \\
\hline
\end{tabular}

Data source: ZEW ICT survey 2010.

\footnotetext{
17This workplace indicator consists of the sum of the following five dummy variables that are each equal to one if the firm offers this management practice: Self-managed teams, units with own profit and loss responsibility, performance pay, job rotation and work time accounts.

${ }^{18}$ Classification of industries 2008 as of "Klassifikation der Wirtschaftszweige 2008 (WZ 2008)". See Table 16 in the Appendix for the exact industry classification.
} 
Since the empirical analysis focuses on the role of ICT on the likelihood of global sourcing, Table 5 shows average values for ICT adoption between firms that source inputs globally and those that do not. For all indicators and ICT variables except for B2C e-commerce in the manufacturing sector, importing firms have higher average values than those firms that do not import. Moreover, the differences in firm characteristics between importing and nonimporting firms found in the literature are generally reflected. In both sectors, global sourcing firms are on average larger, have a higher labour productivity, are more often exporters as well as more of them have a foreign affiliate than firms without any foreign inputs (Table 9 in the Appendix). Furthermore, global sourcing firms are more innovative. With respect to labour productivity, in the manufacturing the mean value for global sourcing firms is almost by one third higher compared to non-importing firms and in the service sector the respective value by one fifth.

The descriptive analysis suggests that global sourcing firms differ in their ICT adoption as well as in other important firm characteristics from firms that do not source globally. As expected by theoretical considerations, on average the diffusion of ICT is larger for global sourcing firms than for those without any inputs imported. However, since a pure mean comparison does not control for firm characteristics that might be deterministic for the global sourcing decision as well as for ICT adoption, a univariate probit model is chosen that controls for such firm characteristics in order to investigate whether more ICT-intensive firms are more likely to source inputs from abroad, conditional on other sources of firm heterogeneity.

\subsection{Econometric implementation}

A univariate probit model is chosen to analyse whether firms with certain ICT characteristics and higher ICT intensity as well as higher labour productivity are more likely to source inputs from abroad. The following equation formalizes the estimating equation:

$$
P\left(Y_{i}=1 \mid X_{i}\right)=\Phi\left(\alpha+\beta_{I C T}^{\prime} I C T_{i}+\gamma l o g\left(\operatorname{prod}_{i}\right)+\delta^{\prime} X_{i}\right)
$$

where $i$ represents the firm indicator and $\Phi($.$) the cumulative standard normal distribution$ given that the probit model assumes the error term to be standard normally distributed. The dependent variable $Y_{i}$ is a dummy variable for global sourcing activity, $I C T_{i}$ is a vector that includes the three types of ICT discussed above and $\log \left(\operatorname{prod}_{i}\right)$ stands for labour productivity included in logarithmic terms. 
$X_{i}$ is a vector of control variables comprising variables that might have an impact on the decision to import inputs as well as on adopting a certain ICT application, as it is discussed above. The probit regressions allow for heteroskedastic error terms by using the robust standard errors estimation.

A potential concern with this empirical approach is that the ICT variables may be endogenous to the global sourcing activity. As the data do not include neither the starting year of importing inputs, nor the adoption year of any of the software systems or the e-commerce solutions, it is impossible to analyse whether ICT can be seen as causing firms to source globally or whether actually global sourcing firms have invested more in ICT solutions because for instance, they assess higher benefits to the use of it. Since this reverse causality problem cannot be addressed with the data, the empirical results are interpreted as correlations between a firm's ICT intensity and global sourcing activity controlling for firm heterogeneity that may be relevant for both decisions. However, at least for the e-selling activities, which are captured in the e-commerce indicator, the relationship to global sourcing is less obvious given that e-selling supports sales and not sourcing activities. Moreover, the general challenge that e-selling activities depend on the product suitability should on average not depend on the upstream composition of the value chain. Therefore, the e-selling activities that are included in the e-commerce count indicator can be seen as plausibly exogenous to global sourcing.

Besides endogeneity due to reverse causality, omitted variables that are correlated with the explanatory variables may bias the coefficient estimates. For instance, unobservable firm effects, such as management quality, idiosyncratic shocks correlated with ICT and global sourcing or policy changes that do not affect all firms within an industry, so that they would not be captured by the industry dummy variable, might lead to a spurious correlation between ICT and global sourcing. If systematically better performing firms invest on average more in ICT and are also more likely to source globally, then the coefficients of ICT will be upward biased. To alleviate endogeneity due to omitted variables, I include a large set of control variables, such as labour productivity or a firm's human capital composition. Hence, the empirical results reflect whether more ICT-intensive firms with similar other firm characteristics are more likely to source inputs globally. Moreover, in addition to the analysis with the total samples of manufacturing and service firms, I examine the relevance of ICT for global sourcing in different subsamples to analyse where the effect of ICT might be expected to be stronger or lower. 


\section{Empirical results}

\subsection{Main results}

Table 6 shows the main results of the probit estimations of equation (1) that links a firm's ICT intensity to its global sourcing status. In all tables, the average marginal effects (sample averages of the changes in the variables of interest evaluated for each observation) are presented. In columns (1) to (4) the results for the manufacturing sector and in columns (5) to (8) for the service sector are depicted that originate from various regression specifications, which differ in the set of control variables. Columns (1) and (5) show the correlations between the ICT variables and global sourcing controlling for firm size, industry dummy variables, location in a new state of Germany, i.e. former East Germany, and multi-plant affiliation. In the manufacturing sector, firms with more e-commerce applications as well as more enterprise software systems are weakly significantly more likely to source inputs from abroad. Moreover, manufacturers with a higher share of employees working predominantly at the PC and with a higher share of employees with Internet access are more likely to source globally. In contrast, in the service sector, only those with more e-commerce applications and weakly those with more enterprise software systems are more likely to import inputs.

In columns (2) and (6) labour productivity is included given that models of firm heterogeneity stress the relevance of firm productivity as key selection factor into production fragmentation and importing (e.g., Antrás and Helpman (2004), Antras et al. (2014)). The coefficients of labour productivity show that for manufacturing as well as for service firms, more productive firms are more likely to source globally. This positive relationship between productivity and global sourcing is compatible with the view in models of firm heterogeneity that global sourcing incurs fixed costs that only the more productive ones can overcome. Columns (3) and (7) consider firms' further international activities in terms of exporting and existence of a foreign location. For both, manufacturing and service firms, if they export, they are more likely to import inputs as well. This result seems reasonable given that exporting firms, for instance, have established foreign contacts, which might facilitate finding foreign suppliers or more generally, maintaining contacts with foreign partners.

Columns (4) and (8) add a variety of controls for skill composition, innovation outcomes and workplace organization. Among these control variables, realized product innovations raise the probability of global sourcing for manufacturing and service firms. Manufacturing firms are also significantly more likely to import inputs with realized process innovations and more forms of decentralized workplace organization. With this set of controls, concerning ICT use, in the manufacturing sector only a higher share of employees with Internet access increases the global sourcing likelihood significantly. In the service sector, only e-commerce activities are correlated positively and significantly with the global sourcing probability. The coefficient of the e-commerce indicator in column (8) suggests that being engaged in 
one more e-commerce-based activity is associated with a 5.4 percentage points increase in the likelihood of global sourcing for service firms.

Table 6: Global sourcing probability and ICT - Average marginal effects

\begin{tabular}{|c|c|c|c|c|c|c|c|c|}
\hline & \multicolumn{4}{|c|}{ Manufacturing sector } & \multicolumn{4}{|c|}{ Service sector } \\
\hline & (1) & (2) & (3) & (4) & $(5)$ & (6) & (7) & (8) \\
\hline & $\begin{array}{l}\text { ICT \& } \\
\text { firm size }\end{array}$ & $\begin{array}{c}\text { Labour } \\
\text { productivity }\end{array}$ & $\begin{array}{c}\text { Interna- } \\
\text { tional } \\
\text { activities }\end{array}$ & $\begin{array}{l}\text { Further } \\
\text { controls }\end{array}$ & $\begin{array}{l}\text { ICT \& } \\
\text { firm size }\end{array}$ & $\begin{array}{c}\text { Labour } \\
\text { productivity }\end{array}$ & $\begin{array}{c}\text { Interna- } \\
\text { tional } \\
\text { activities }\end{array}$ & $\begin{array}{l}\text { Further } \\
\text { controls }\end{array}$ \\
\hline E-Commerce-Indicator & $\begin{array}{l}0.030^{*} \\
(0.016)\end{array}$ & $\begin{array}{l}0.033^{* *} \\
(0.016)\end{array}$ & $\begin{array}{c}0.022 \\
(0.015)\end{array}$ & $\begin{array}{c}0.015 \\
(0.015)\end{array}$ & $\begin{array}{c}0.065^{* * *} \\
(0.015)\end{array}$ & $\begin{array}{c}0.066^{* * *} \\
(0.015)\end{array}$ & $\begin{array}{c}0.059^{* * *} \\
(0.014)\end{array}$ & $\begin{array}{c}0.054^{* * *} \\
(0.015)\end{array}$ \\
\hline Enterprise Software-Indicator & $\begin{array}{l}0.024^{* *} \\
(0.012)\end{array}$ & $\begin{array}{l}0.022^{*} \\
(0.012)\end{array}$ & $\begin{array}{c}0.012 \\
(0.012)\end{array}$ & $\begin{array}{l}-0.001 \\
(0.012)\end{array}$ & $\begin{array}{l}0.022^{*} \\
(0.013)\end{array}$ & $\begin{array}{c}0.019 \\
(0.013)\end{array}$ & $\begin{array}{c}0.011 \\
(0.012)\end{array}$ & $\begin{array}{c}0.008 \\
(0.013)\end{array}$ \\
\hline \% empl. working with PC & $\begin{array}{l}0.137^{*} \\
(0.074)\end{array}$ & $\begin{array}{l}0.080 \\
(0.075)\end{array}$ & $\begin{array}{c}0.021 \\
(0.072)\end{array}$ & $\begin{array}{l}0.026 \\
(0.075)\end{array}$ & $\begin{array}{l}-0.044 \\
(0.055)\end{array}$ & $\begin{array}{l}-0.060 \\
(0.054)\end{array}$ & $\begin{array}{l}-0.044 \\
(0.053)\end{array}$ & $\begin{array}{l}-0.033 \\
(0.055)\end{array}$ \\
\hline$\%$ empl. with Internet access & $\begin{array}{l}0.170^{* * * *} \\
(0.054)\end{array}$ & $\begin{array}{c}0.152^{* * *} \\
(0.054)\end{array}$ & $\begin{array}{c}0.151^{* * *} \\
(0.051)\end{array}$ & $\begin{array}{c}0.148^{* * *} \\
(0.051)\end{array}$ & $\begin{array}{c}0.083 \\
(0.060)\end{array}$ & $\begin{array}{c}0.062 \\
(0.060)\end{array}$ & $\begin{array}{c}0.068 \\
(0.058)\end{array}$ & $\begin{array}{c}0.055 \\
(0.060)\end{array}$ \\
\hline $\ln$ (employment) & $\begin{array}{c}0.078^{* * *} \\
(0.011)\end{array}$ & $\begin{array}{c}0.067^{* * *} \\
(0.012)\end{array}$ & $\begin{array}{c}0.034^{* * * *} \\
(0.012)\end{array}$ & $\begin{array}{c}0.021 \\
(0.014)\end{array}$ & $\begin{array}{c}0.012 \\
(0.011)\end{array}$ & $\begin{array}{l}0.010 \\
(0.011)\end{array}$ & $\begin{array}{c}0.005 \\
(0.011)\end{array}$ & $\begin{array}{c}0.002 \\
(0.014)\end{array}$ \\
\hline $\ln$ (labour productivity) & & $\begin{array}{c}0.077^{* * *} \\
(0.020)\end{array}$ & $\begin{array}{l}0.047^{* *} \\
(0.020)\end{array}$ & $\begin{array}{l}0.047^{* *} \\
(0.020)\end{array}$ & & $\begin{array}{c}0.052^{* * *} \\
(0.019)\end{array}$ & $\begin{array}{l}0.041^{* *} \\
(0.018)\end{array}$ & $\begin{array}{l}0.040^{* *} \\
(0.018)\end{array}$ \\
\hline export activity & & & $\begin{array}{c}0.265^{* * *} \\
(0.027)\end{array}$ & $\begin{array}{c}0.264^{* * *} \\
(0.027)\end{array}$ & & & $\begin{array}{c}0.183^{* * *} \\
(0.025)\end{array}$ & $\begin{array}{c}0.178^{* * *} \\
(0.025)\end{array}$ \\
\hline foreign location & & & $\begin{array}{l}0.066^{*} \\
(0.040)\end{array}$ & $\begin{array}{l}0.060 \\
(0.040)\end{array}$ & & & $\begin{array}{l}0.056 \\
(0.039)\end{array}$ & $\begin{array}{c}0.059 \\
(0.039)\end{array}$ \\
\hline \% highly skilled empl. & & & & $\begin{array}{l}-0.081 \\
(0.093)\end{array}$ & & & & $\begin{array}{l}-0.031 \\
(0.054)\end{array}$ \\
\hline product innovation & & & & $\begin{array}{l}0.051^{*} \\
(0.027)\end{array}$ & & & & $\begin{array}{l}0.059^{* *} \\
(0.029)\end{array}$ \\
\hline process innovation & & & & $\begin{array}{l}0.048^{*} \\
(0.027)\end{array}$ & & & & $\begin{array}{l}-0.012 \\
(0.028)\end{array}$ \\
\hline works council & & & & $\begin{array}{c}0.011 \\
(0.035)\end{array}$ & & & & $\begin{array}{c}0.010 \\
(0.037)\end{array}$ \\
\hline workplace organization & & & & $\begin{array}{l}0.025^{* *} \\
(0.012)\end{array}$ & & & & $\begin{array}{c}0.003 \\
(0.012)\end{array}$ \\
\hline sector and location dummies & yes & yes & yes & yes & yes & yes & yes & yes \\
\hline number of observations & 1243 & 1243 & 1243 & 1243 & 894 & 894 & 894 & 894 \\
\hline Pseudo- $R^{2}$ & 0.1030 & 0.1124 & 0.1632 & 0.1716 & 0.0952 & 0.1059 & 0.1702 & 0.1757 \\
\hline
\end{tabular}

\subsection{Robustness checks}

Thus far, I have examined the average effect of ICT on the probability of global sourcing, conditional on other sources of firm heterogeneity. In the following, first, I will present some robustness checks with additional control variables or different ICT measures. Second, I will examine the relationship between ICT and global sourcing for different subsamples and third, I will analyse a particular circumstance under which ICT might be particularly relevant for global sourcing. Finally, I will consider SMEs only.

\subsubsection{Additional control variables and ICT measures}

Table 10 shows results for the manufacturing sector with the set of controls as in column (4) of Table 6. For all these specifications, the central result from the main analysis for 
manufacturing firms that the share of employees with Internet access and labour productivity are significantly positively related to global sourcing is robust. In column (1), instead of including two-digit industry dummy variables, three-digit industry dummy variables are considered. They are not used for the main analysis because in some three-digit industries all firms import inputs so that those firms will not be used in the estimation as the three-digit dummy variable predicts global sourcing perfectly. Column (2) includes dummy variables for the second and third tertile of the labour productivity distribution instead of the logarithmized productivity. The reference group are those firms in the first productivity tertile. This strategy is based on Fort (2015) who uses indicators for the productivity distribution in order to allow for potential non-linearities in the effect of productivity. The results show that those firms in the top productivity tertile are on average 8.2 percentage points more likely to source inputs from abroad. Similarly, Fort (2015) finds that only firms in the top of the productivity distribution are significantly more likely to offshore but not those in the middle group. In column (3), IT outsourcing is taken into account. ICT-intensive firms might be more likely to source out IT and to import inputs. For example, they might import IT support, i.e. the IT outsourcing from abroad. However, the coefficient of IT outsourcing is not significant and all other coefficients do not change neither qualitatively nor quantitatively very much.

Columns (4) to (6) include different variants of ICT indicators. Column (4) considers a count indicator that adds the number of e-commerce and software applications into one indicator. Column (5) includes the individual dummy variables for e-commerce and the software systems. Finally, column (6) introduces indicators based on the usage intensity of the e-commerce activities and of the software systems. The ICT survey 2010 asks the firms about each e-commerce use and enterprise software system whether they do not use it, use it only sporadically or use it broadly. This categorical information from zero to two is used to create a usage intensity indicator by z-scoring the values for each application and then adding the individually z-scored values and using the z-scoring transformation again. None of these various ICT variables is significantly related to global sourcing.

Table 11 shows the same set of regression specifications for service firms. The central result from the baseline analysis that an additional e-commerce use raises the global sourcing probability is robust to the different control variables and for the different ICT indicators. The result of column (5), in which each of the ICT applications considered for the indicators, are included as dummy variables, gives some insight which of the e-commerce applications is the most relevant for global sourcing. As consistent with the purpose of this Internet-based transaction, it is the use of Internet ordering whose coefficient has the largest magnitude. According to the result in column (5), firms that use Internet ordering are 12.2 percentage points more likely to source inputs from abroad. Although the results of Abramovsky and Griffith (2006) are not completely comparable to those in this paper since they only consider business services offshoring, the authors also find that using the Internet to order goods 
increases the offshoring probability significantly for UK firms. Column (5) also shows that neither B2B nor B2C e-selling is individually significantly related to global sourcing reflecting that it is not e-selling transactions per se that raise the global sourcing probability. To test whether besides e-buying, the intensity of e-selling raises the global sourcing likelihood, column (7) includes a count variable for e-selling based on B2B and B2C e-commerce. The result shows that in addition to Internet ordering, more uses of e-selling are positively associated with global sourcing at the 10-percent significance level. This result suggests that firms that rely on more electronic-based transactions are more likely to be an importing firm, too.

\subsubsection{Different subsamples of firms}

Second, to gauge whether the results are robust for different subsets of firms and to analyse for which firms ICT seems to be more relevant for global sourcing, Tables 12 and 13 show results for different subsets of manufacturing and service firms, respectively. Thus far, I have not distinguished between firms without and with a foreign location. Hence, the results have represented the relevance of ICT for sourcing inputs across borders, irrespective of whether the transactions take part within or across firm boundaries. Coordination costs across borders and firm boundaries will probably on average be higher than coordination across borders within firm boundaries so that ICT-facilitated coordination may be particularly useful. Column (1) shows the results for firms without any foreign location. Therefore, in addition to trading across borders, those firms trade across firm boundaries for sourcing their inputs from abroad. Since the results do not differ qualitatively nor quantitatively very much from those including also firms with a foreign location (see Table 6, column (4)), in the following, I present the results for firms with and without a foreign location together, if not stated otherwise.

Given the high marginal effect of export activities on the probability of global sourcing, column (2) presents results for the subsample of exporting firms only. Thus, all those firms sell at least part of their output in at least one other country than Germany. Therefore, they will have some knowledge about other foreign markets, which might help them to find international suppliers, too. While in general the results do not change very much in comparison to the results for the total sample, the coefficient of labour productivity decreases in size in comparison to the coefficient for productivity as in the baseline specification (Table 6, column (4)) and turns insignificant. This reduction in the contribution of productivity seems plausible because only exporters are considered which according to heterogeneous firm models of international trade are more productive than non-exporters. As those latter are not considered in column (2), the remaining firms are on average already more productive than all firms in the total sample. Since the sorting of the productivity level needed for importing in comparison to exporting has not been yet uniquely established in heterogeneous firm models and prior findings suggest that on average firms that only export services but do not 
import them are more productive than service importing only firms (Breinlich and Criscuolo (2011)), it seems also plausible that increasing labour productivity does not significantly raise the importing likelihood. All those firms had to overcome at least some sort of fixed foreign market entry cost for exporting. Consequently, they might be able to overcome the fixed costs of importing too, so that productivity is not a central distinguishing factor.

Column (3) addresses the potential concern that in the total sample firms who source inputs are compared with firms who produce everything at their plant so that they would not need importing anything from abroad. To make the sample of firms more comparable, in column (3) only firms who indicate to order inputs from suppliers online are considered. Optimally, information about domestic sourcing would suffice to compare firms that source inputs. Since the data do not include information about domestic sourcing but only about foreign sourcing, I use the information about Internet ordering from suppliers to infer that a firm sources at least some inputs from a physically distant supplier, either domestically or from abroad. As the restriction is based on Internet ordering and therefore excludes all firms that source from suppliers without using the Internet, the remaining sample will probably be smaller than conditioning only on input sourcing. Moreover, all those firms have some experience with e-commerce, at least with e-buying. The results show that the marginal effect of the share of employees with Internet access decreases in magnitude but remains significant at the 10-percent level. This result provides some evidence that even among input sourcing firms, more ICT-intensive firms in terms of Internet access diffusion are more likely to import inputs.

Table 13, columns (1) to (3), presents the results from the different subsamples for service firms in the same order of restrictions as in Table 12, columns (1) to (3). The central finding from the main analysis that more uses of e-commerce increase the global sourcing probability is robust to the different restrictions. The relationship between e-commerce and global sourcing is positive and significant for service firms without a foreign location, among exporting firms only as well as among firms that use Internet ordering.

\subsubsection{Upstream industry diversity}

A particular circumstance in which the contribution of ICT for global sourcing might be expected to be particularly relevant is when firms source inputs from many different suppliers. This might result in a more complex supply chain so that the coordination costs of firms with multiple suppliers will probably be particularly high. Hence, ICT-facilitated coordination might decrease the coordination costs for these firms disproportionately more than for firms with only very few suppliers. Lacking data on the individual firm's number of different suppliers, I exploit industry variation in the number of different industries from which a particular industry sources inputs. I use information from the input-output (IO) tables from 2009 published by the German Federal Statistical Office in order to compute an industry's 
ratio of the number of industries with positive inputs sourced domestically and the number of industries with positive inputs from abroad over two times the total number of possible industries to source from. The following formula summarizes the calculation:

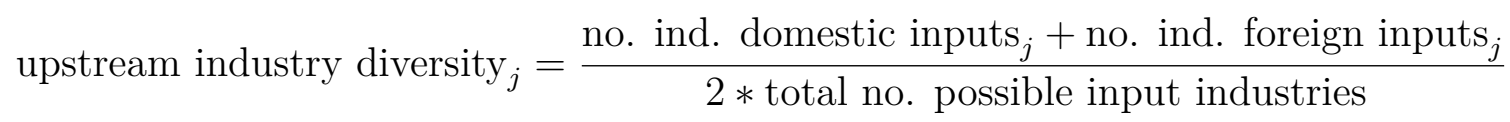

where $\mathrm{j}$ stands for the industry and the total number of possible domestic or foreign input industries is 73 for each based on the German IO tables. For instance, according to the IO tables in 2009, the chemical industry sources inputs from 63 industries domestically and imports inputs from 47 industries. Computing the ratio of this number of industries with positive inputs over two times the total number of possible input industries, i.e. $2 * 73$, yields a ratio of 0.75 . Using this ratio, I categorize each industry considered in the ICT survey based on the median value of this measure within the industries in the ICT survey either into the group of industries with many upstream relationships, i.e. higher upstream industry diversity, if the ratio is strictly above the median or into the group with less upstream relationships, i.e. lower upstream industry diversity, if the value is below or equal to the median. As this measure is based on industry-level and not firm-level information and it includes the extent of domestic input sourcing as well as of global sourcing, the categorization of industries into higher and lower upstream industry diversity will likely not be selection on the firm-level dependent variable global sourcing. The hypothesis is that for firms in industries with higher upstream industry diversity, the marginal effect of ICT for global sourcing is expected to be larger than for firms in an industry with a lower diversity in upstream industries.

This measure of upstream industry diversity also reflects the upstream supply chain complexity of an industry because it measures with how many different industries a particular industry trades upstream. By construction, this measure of upstream industry diversity captures two sources of variation. On the one hand, the number of industries a particular industry sources inputs from domestically. On the other hand, it captures the extent to which the input sourcing is from abroad. Potentially, both sources of variation may contribute to industry-level supply chain complexity. In the following, the terms upstream industry diversity and upstream supply chain complexity are used interchangeably. For more information about the construction of this measure, values for the different industries and alternative measures, see A.2 in the Appendix.

Subject to this definition of upstream industry diversity, in the manufacturing sector, the chemical and pharmaceutical industry, the machine construction, and the vehicle construction industries are classified into the group of higher upstream industry diversity, and consequently the other industries (consumer goods, other raw materials, metal industry, electrical 
engineering) into the group of lower upstream industry diversity. ${ }^{19}$ Columns (4) to (7) in Table 12 show the results for the former, and columns (8) to (11) for the latter group by restricting in columns (5) and (9) also on firms without foreign location, in columns (6) and (10) on exporting firms and in columns (7) and (11) on firms who use e-buying from suppliers. This sample splitting yields that in the group of firms with higher industry-level upstream industry diversity, there is some evidence that more uses of e-commerce increase the global sourcing probability, although with weak significance, while the share of employees with Internet access is not significantly related to global sourcing (columns (4) and (5)). This result is similar to the findings for the role of e-commerce in the service sector. In contrast, for firms with lower upstream industry diversity this result is reversed and is similar to the results for the total manufacturing sector. The results from this sample splitting suggest that similar to the service sector, in manufacturing industries with high upstream supply chain complexity, e-commerce activities are positively associated with global sourcing of inputs. In those industries with a large number of industries with positive inputs, the differences in the share of employees with Internet access between importers and non-importers is smaller than in the other manufacturing industries, which explains partly why for them the relationship between the Internet access share and importing is insignificant.

In the service sector, according to the definition of upstream industry diversity as explained above, the IT and other information services, the business consultancy and advertising, the technical services and the other business services industries are categorized into the group with higher upstream industry diversity. ${ }^{20}$ As hypothesized, for firms in industries with higher upstream supply chain complexity (Table 13, columns (4) to (7)), the marginal effect of an additional e-commerce activity is larger than for firms with a lower intensity (Table 13, columns (8) to (10)). ${ }^{21}$ These results support the conclusion that in industries with complex supply chains in terms of the number of diverse upstream industries, e-commerce is particularly relevant for global sourcing and that Internet-enabled coordination across distance may lower the associated costs.

Furthermore, in both sectors, only for those industries with higher upstream industry diversity, the association between labour productivity and global sourcing is significant, which might be because a high productivity level is needed to source from different industries. This result is compatible with the heterogeneous firm model for global sourcing decisions by Antras et al. (2014). In this model, the authors establish a positive relationship between firm

\footnotetext{
${ }^{19}$ Those industries reflect also highest upstream industry diversity, i.e. a ratio above the total sector median, when the number of the domestic industries with positive input values, the number of industries with positive imports or the number of industries with either domestic or foreign inputs are considered in comparison to the total number of possible input industries. For further information, see A.2 in the Appendix.

${ }^{20}$ The same industries are identified when considering alternative counts of the number of industries with positive inputs; see also A.2 in the Appendix.

${ }^{21}$ The results for the subsample of exporting firms in industries with lower upstream industry diversity are not presented because the sample size is only 75 firms for four industries so that no reasonable conclusions can be made.
} 
productivity and the number of countries a firm can import from because the increasing productivity level is needed to overcome the fixed costs of each additional import market entry. The results suggest that in industries with lower upstream industry diversity, productivity is not a critical factor, upon which importing firms differ from non-importing firms.

\subsection{SMEs}

Finally, the analysis is conducted for the subsample of SMEs only. Even though 86 percent of the manufacturing sector sample and 88 percent of the service sector sample are SMEs, it might be that the results for this subsample of firms differ from the total sample including large firms because prior evidence often finds that smaller firms benefit less from IT (e.g., Tambe and Hitt (2012), Rasel (2015)). However, for the relationship between ICT and global sourcing, the results for SMEs do not differ qualitatively nor quantitatively a lot from the results with the total sample neither in the manufacturing sector (Table 14 in the Appendix) nor in the service sector (Table 15 in the Appendix).$^{22}$

\subsection{Discussion of the results}

The results reflect some similarities and differences in the relevance of particular ICT for global sourcing between manufacturing and service firms. As already suggested by the descriptive statistics, service importers and non-importers do not differ significantly in the average computer work and Internet access shares, while manufacturing firms do. The descriptive statistics and the empirical results from the probit regressions are compatible with the fact that the task composition of the services provided by the service firms considered in this analysis are often highly dependent on computer and Internet work, so that computerbased work and levels of access to the Internet are no distinguishing factors between importers and non-importers in the service sector. However, for manufacturing firms, in which a large fraction of workers work with machines or other technical devices than the computer, ${ }^{23}$ the results show that manufacturing firms, in which more employees have access to the Internet, are more likely to import. The positive relationship between Internet access diffusion among employees and global sourcing is especially found in industries with a lower upstream industry diversity. This result might reflect that those firms require a larger back office than nonimporters in order to manage the firm and in particular the import and input transactions.

Another potential explanation could be that those importing manufacturing firms have more computer-based work processes. Moreover, such a technology diffusion pattern that docu-

\footnotetext{
${ }^{22}$ The results for large firms are not presented as the resulting samples are too small to make meaningful conclusions based on them.

${ }^{23}$ The labour heterogeneity measures for computer work and Internet access refer only to work with personal computers. There is no information in the ICT survey 2010 about the degree of digitization of machines.
} 
ments differences between internationally active and domestically operating firms is consistent with heterogeneous firm models in exporting that establish that exporting firms can invest into higher levels of advanced technology because they have the necessary productivity level not only for exporting but also for buying more advanced technologies (e.g., Lileeva and Trefler (2010), Bustos (2011)). In the case of Internet access, it might be that importing firms can afford to equip a larger fraction of their employees with Internet access.

In contrast, in the service sector, firms with a higher e-commerce intensity are more likely to import inputs. The marginal effect of the use of an additional e-commerce application is particularly high in industries with higher upstream industry diversity. Under that circumstance, there is some weak evidence for a positive marginal effect of e-commerce intensity on global sourcing in the manufacturing sector, too. However, in general, the results of the association between e-commerce and global sourcing are much stronger in services than in manufacturing. On the one hand, this is reflected by larger marginal effects with values of a 5 to 6 percentage points increase in the service sector in comparison to a 1 to 3 percentage points increase in the manufacturing sector (Table 6). On the other hand, the base rate of global sourcing in the service sector is with an average global sourcing participation of 20.1 percent nearly three times smaller than the average global sourcing participation in manufacturing of 59.5 percent. Consequently, the marginal effects relative to the base are even stronger in services. For example, column (2) of Table 6 says that e-commerce is associated with a 3.3 percentage points increase in the likelihood of global sourcing in manufacturing, while for services (column (6)) it is 6.6 percentage points. Given the different average global sourcing participation rates, taking the results at face value, they would imply that e-commerce is associated with around a 5.5 percent change in global sourcing in manufacturing and a 32.8 percent change in services. Thus, the economic magnitudes of e-commerce on global sourcing are much larger in the service than in the manufacturing sector, at least in the year 2009 from which the data are.

In general, the results of a positive association between e-commerce and global sourcing are consistent with the view that transactions with suppliers and customers on electronic market places reduce communication and coordination costs as it has been found already in prior work (Abramovsky and Griffith (2006), Hyun (2010), Fort (2015)). The result that also downstream-related business strategies like e-selling raise the sourcing likelihood could reflect that IT-enabled coordination costs reduction is particularly large if the firm has adopted supplier and customer IT together as it is demonstrated in Forman and McElheran (2015). The authors show that the use of externally-focused IT has led to a decrease in downstream vertical integration and that the effect is largest when both upstream- and downstream-oriented IT, i.e. IT-enabled coordination with suppliers and customers, are adopted together. ${ }^{24}$

\footnotetext{
${ }^{24}$ For a detailed discussion about the role of externally-focused IT on reducing supply chain frictions, see Forman and McElheran (2015).
} 
A possible conjecture might be that the potential of Internet-based coordination and communication to reduce the associated costs with foreign business partners will only be realized if also firms in the country from which German firms import have the necessary technological level so that Internet-based communication across borders and distance is possible at all. The data do not include information about the firms' import countries to control for it. At the aggregate level, the top countries in terms of value German firms imported products from in 2009 were the Netherlands, China, France, the U.S., Italy and the UK (Meyer (2010)). The top countries for service imports in the period from 2001 to 2010 were the U.S., the UK, the Netherlands, Switzerland, France and Austria (Biewen et al. (2013)). These statistics provide some evidence that the majority of import-related business activities by German firms in that period has been with countries with a comparable technology and Internet infrastructure level. Thus, it seems possible that the importing firms actually communicated over the Internet with their foreign business partners.

In the manufacturing sector, on average e-commerce activities do not increase the global sourcing probability robustly in contrast to the results from the service sector or from prior work based on manufacturing firms with evidence from the end-1990s or the early years of 2000 (e.g., Hyun (2010)). One potential reason for this, which is also reflected by the descriptive statistics that differentiate between global sourcing status, might be that in the survey reference year 2009, e-commerce uses have been already more broadly diffused among firms with similar firm characteristics in the manufacturing sector than in the service sector, regardless of the global sourcing status. For instance, in general manufacturing firms have higher input requirements than service firms as shown in the industry-level inputoutput tables. It might be that the non-importing firms source inputs only domestically and therefore, they use e-commerce solutions for these domestic activities. However, as the data do not include information about domestic sourcing, this hypothesis cannot be tested.

In both sectors, enterprise software intensity does not seem to be a distinguishing factor between importers and non-importers of similar characteristics. Given that the software systems considered in the analysis help organizing information from various business processes and do not exclusively provide support in managing externally-focused transactions with suppliers or customers like e-commerce, this result reflects that at least for these software systems, importing firms have not adopted them significantly more than non-importers. These systems have existed, at least in basic form, already at the end of the 1990s so that the diffusion process may have come to a saturation point in the survey year of 2010 . Hence, there are no differences between importers and non-importers any longer, if they have ever been. $^{25}$

Moreover, the results show that if firms export, they are also more likely to import in the manufacturing as well as the service sector. Similarly, in both sectors, more productive firms

\footnotetext{
${ }^{25}$ For instance, importing firms may have adopted the systems earlier because they needed them or could rather afford them. However, with the data, this hypothesis cannot be further explored.
} 
from industries with higher upstream industry diversity are more likely to source inputs from abroad. This finding is compatible with prior results for manufacturing firms that suggest self-selection of more productive firms into offshoring (e.g., Wagner (2011), Fort (2015)) and it confirms predictions of heterogeneous firm models developed mainly for firms producing goods, i.e. manufacturing firms (e.g., Antrás and Helpman (2004)). The positive relationship between productivity and global sourcing is also compatible with studies that find positive productivity effects from input importing (e.g., Halpern et al. (2015)).

\section{Conclusion}

Facilitating coordination across distance and changing work processes, modern ICT and the diffusion of the Internet are seen as important drivers behind the global increase in trade in intermediate goods and also in services. This paper provides new findings for the relevance of ICT on global sourcing activities of inputs for manufacturing firms as well as first evidence for service firms. The results show differences in the role of ICT for global sourcing between manufacturing and service firms. In the manufacturing sector, a higher share of employees with Internet access increases the global sourcing probability in industries with lower upstream supply chain complexity. In the service sector, the probability of sourcing inputs from abroad is increasing in the firm's e-commerce intensity with a larger marginal effect than in the manufacturing sector. The strong association between e-commerce and global sourcing in services is also found for sourcing activities across firm boundaries and the effect is largest for firms in industries with higher upstream supply chain complexity. Under that circumstance, e-commerce weakly increases the global sourcing probability in the manufacturing sector, too. These results provide evidence that e-commerce lowers coordination costs of managing business relationships across distance. Overall, the results suggest that it is not necessarily ICT intensity per se that increases the global sourcing probability but it depends on the type of ICT and also on sector-specific differences in work processes and in diffusion processes of ICT between the manufacturing and service sector. However, for both sectors, the results underline the role of Internet-based activities for global sourcing activities.

Furthermore, in both sectors, more productive firms are more likely to source inputs from abroad, especially in industries that source inputs from many different industries. This result confirms the importance of productivity for importing decisions highlighted in heterogeneous firm models of international trade (e.g., Antrás and Helpman (2004), Antras et al. (2014)) and the productivity advantage of internationally active firms (e.g., Bernard et al. (2012), Wagner (2011)). Since empirical evidence about service firms in international trade is still scarce and heterogeneous firm models are mainly developed for goods-producing firms, the empirical results in this paper provide supportive evidence for the view that models for goods-producing firms are a good starting point for the analysis of service trade (Breinlich 
and Criscuolo (2011)).

Certain limitations of the analysis point to potential opportunities for future research. Due to data limitations, the empirical analysis could not distinguish which types of goods or services and from which countries the firms imported. Given ongoing discussions about trade liberalization reforms for goods and services and the efforts to establish a single digital market in Europe, ${ }^{26}$ analysing which kinds of inputs are sourced in different industries and in how far the technological intensity and other firm characteristics play a role, may be important to assess which types of inputs might be sourced in the future even more, thereby possibly substituting domestically produced inputs. Moreover, the different global sourcing behaviour according to technology intensity and productivity levels may have implications for the firms' performance outcomes, such as productivity or innovation. Since existing research shows that ICT and also input importing may be productivity-enhancing as well as enablers for innovation, future trade liberalization reforms and reductions in online trade barriers might enlarge the performance gap between globally active and non-active firms. Investigating further the interactions between ICT, importing and productivity can help to understand better why internationally active firms are on average more productive, even in the service sector, which is usually less trade intensive than the manufacturing sector.

\footnotetext{
${ }^{26}$ For more information about the European Commission's aim and strategies to develop a digital single market in the European Union, see for instance http://ec.europa.eu/digital-agenda/en/digital-single-market
} 


\section{References}

Abramovsky, L. and R. Griffith (2006). Outsourcing and offshoring of business services: How important is ICT? Journal of the European Economic Association 4(2-3), 594-601.

Amiti, M. and J. Konings (2007). Trade liberalization, intermediate inputs, and productivity: Evidence from Indonesia. American Economic Review 97(5), 1611-1638.

Amiti, M. and S.-J. Wei (2009). Service offshoring and productivity: Evidence from the US. The World Economy 32(2), 203-2020.

Antras, P., T. C. Fort, and F. Tintelnot (2014). The margins of global sourcing: Theory and evidence from U.S. firms. R\&R at the American Economic Review.

Antrás, P. and E. Helpman (2004). Global sourcing. Journal of Political Economy 112(5), $552-580$.

Aral, S., E. Brynjolfsson, and D. Wu (2006, October). Which came first, IT or productivity? The virtuous cycle of investment and use in enterprise systems. Twenty Seventh International Conference on Information Systems, Milwaukee 2006.

Ariu, A. (2015). Services versus goods trade: A firm-level comparison. Review of World Economics, forthcoming.

Autor, D. H., F. Levy, and R. J. Murnane (2003). The skill content of recent technological change: An empirical exploration. Quarterly Journal of Economics 118(4), 1279-1333.

Benfratello, L., T. Razzolini, and A. Sembenelli (2015). Does ICT investment spur or hamper offshoring? Empirical evidence from microdata. IZA DP No. 9239.

Bernard, A. B., J. B. Jensen, S. J. Redding, and P. K. Schott (2007). Firms in international trade. Journal of Economic Perspectives 21 (3), 105-130.

Bernard, A. B., J. B. Jensen, S. J. Redding, and P. K. Schott (2012). The empirics of firm heterogeneity and international trade. Annual Review of Economics 4, 283-313.

Bertschek, I., J. Hogrefe, and F. Rasel (2015). Trade and technology: New evidence on the productivity sorting of firms. Review of World Economics 151(1), 53-72.

Bertschek, I. and U. Kaiser (2004). Productivity effects of organizational change: Microeconometric evidence. Management Science 50(3), 394-404.

Bertschek, I. and J. Meyer (2009). Do older workers lower IT-enabled productivity? Firmlevel evidence from Germany. Jahrbücher für Nationalökonomie und Statistik 229(2+3), $327-342$. 
Biewen, E., S. Blank, and S. Lohner (2013, February). Microdatabase: Statistics on international trade in services. Deutsche Bundesbank.

Bloom, N., R. Sadun, and J. V. Reenen (2012). Americans do IT better: US multinationals and the productivity miracle. American Economic Review 102(1), 167-201.

Breinlich, H. and C. Criscuolo (2011). International trade in services: A portrait of importers and exporters. Journal of International Economics 84, 188-206.

Bresnahan, T. F., E. Brynjolfsson, and L. M. Hitt (2002). Information technology, workplace organization, and the demand for skilled labor: Firm-level evidence. The Quarterly Journal of Economics 117(1), 339-376.

Brynjolfsson, E. and A. Saunders (2010). Wired for Innovation: How IT is Reshaping the Economy. The MIT Press.

Bustos, P. (2011). Trade liberalization, exports, and technology upgrading: Evidence on the impact of Mercosur on Argentinian firms. American Economic Review 101(1), 304-340.

Caliendo, L. and E. Rossi-Hansberg (2012). The impact of trade on organization and productivity. Quarterly Journal of Economics 127(3), 1393-1467.

Cardona, M., T. Kretschmer, and T. Strobel (2013). The contribution of ICT to productivity: Key conclusions from surveying the empirical literature. Information Economics and Policy 25 (3), 109-125.

Chopra, S. and P. Meindl (2007). Supply Chain Management. Strategy, Planning \& Operations, Volume Third Edition. Pearson Prentice Hall.

Criscuolo, C., J. E. Haskel, and M. J. Slaughter (2005). Global engagement and the innovation activities of firms. NBER Working Paper 11479.

Draca, M., R. Sadun, and J. V. Reenen (2007). Productivity and ICTs: A review of the evidence. In R. Mansell, C. A. D. Quah, and R. Silverstone (Eds.), The Oxford Handbook of Information and Communication Technologies, pp. 100-147. Oxford University Press.

Engelstätter, B. (2012). It's not all about performance gains - enterprise software and innovations. Economics of Innovation and New Technology 21(3), 223-245.

Forman, C. and K. McElheran (2015). The digital reorganization of firm boundaries: IT use and vertical integration in U.S. manufacturing. R\&R at Management Science.

Fort, T. C. (2015). Technology and production fragmentation: Domestic versus foreign sourcing. R\&R at the Review of Economic Studies.

Freund, C. L. and D. Weinhold (2002). The internet and international trade in services. American Economic Review 92(2), 236-240. 
Glass, A. J. and K. Saggi (2001). Innovation and wage effects of international outsourcing. European Economic Review 45, 67-86.

Görg, H. and A. Hanley (2011). Services outsourcing and innovation: An empirical investigation. Economic Inquiry 49(2), 321-333.

Görg, H., A. Hanley, and E. Strobl (2008). Productivity effects of international outsourcing: Evidence from plant-level data. Canadian Journal of Economics 41, 2.

Grossman, G. G. and E. Helpman (2002). Integration versus outsourcing in industry equilibrium. Quarterly Journal of Economics 117, 85-120.

Grossman, G. G. and E. Rossi-Hansberg (2007). The rise of offshoring: It's not wine for cloth anymore. In The New Economic Geography: Effects and Policy Implications, Federal Reserve Bank of Kansas City, Jackson Hole Symposium.

Grossman, G. M. and E. Rossi-Hansberg (2008). Trading tasks: A simple theory of offshoring. American Economic Review 98(5), 1978-1997.

Haller, S. A. and I. Siedschlag (2011). Determinants of ICT adoption: Evidence from firmlevel data. Applied Economics 43, 3775-3788.

Halpern, L., M. Koren, and A. Szeidl (2015). Imported inputs and productivity. American Economic Review 105(12), 3660-3703.

Hindricks, K. B., V. R. Singhal, and J. K. Stratman (2007). The impact of enterprise systems on corporate performance: A study of ERP, SCM, and CRM system implementations. Journal of Operations Management 25, 65-82.

Hollenstein, H. and M. Wörter (2008). Inter- and intra-firm diffusion of technology: The example of e-commerce. Research Policy 37, 545-56.

Hyun, H.-J. (2010). Firm heterogeneity in the choice of offshoring: Evidence from Korean manufacturing firms. Asean Economic Papers 9(1), 157-178.

Kelle, M. and J. Kleinert (2010). German firms in service trade. Applied Economics Quarterly 56(1), 51-72.

Lileeva, A. and D. Trefler (2010). Improved access to foreign markets raises plant-level productivity ... for some plants. Quarterly Journal of Economics 125(3), 1051-1099.

McElheran, K. (2015). Do market leaders lead in business process innovation? The case(s) of e-business adoption. Management Science 61(6), 1197-1216.

Melitz, M. (2003). The impact of trade on intra-industry reallocation and aggregate industry productivity. Econometrica 71(6), 1695-1725. 
Meyer, S. (2010). Der deutsche Außenhandel im Sog der Weltwirtschaftskrise. Entwicklungen im Jahr 2009. Statistisches Bundesamt, Wirtschaft und Statistik.

Olsen, K. B. (2006). Productivity impacts of offshoring and outsourcing: A review. OECD, STI Working Paper 1.

Rasel, F. (2015). Combining information technology and decentralized workplace organization: Smes versus larger firms. International Journal of the Economics of Business, forthcoming.

Redding, S. J. (2011). Theories of heterogeneous firms and trade. Annual Review of Economics 3, 77/105.

Tambe, P. and L. M. Hitt (2012). The productivity of information technology investments: New evidence from IT labor data. Information Systems Research 23(3), 599-617.

Timmer, M., R. Inklaar, M. O’Mahony, and B. V. Ark (2010). Economic Growth in Europe. Cambridge University Press.

Tomiura, E. (2005). Foreign outsourcing and firm-level characteristics: Evidence from Japanese manufacturers. Journal of the Japanese and International Economies 19(2), $255-271$.

Violante, G. L. (2008). Skill-biased technological change. In The New Palgrave Dictionary of Economics, Online Edition (Second ed.). Steven N. Durlauf and Lawrence E. Blume.

Vogel, A. and J. Wagner (2010). Higher productivity in importing German manufacturing firms: Self-selection, learning from importing, or both? Review of World Economics 145, $641-665$.

Wagner, J. (2011). Offshoring and firm performance: Self-selection, effects on performance, or both? Review of World Economics 147(2), 217-247. 


\section{A Appendix}

\section{A.1 Additional tables}

Table 7: Industry distribution in full sample and the complete data set from 2010

\begin{tabular}{lcccc}
\hline \hline Industry & obs. & \% of sample & obs. & \% of data set \\
\hline \hline Consumer goods & 324 & 15.16 & 504 & 14.38 \\
Chemical and pharmaceutical industry & 104 & 4.87 & 171 & 4.88 \\
Other raw materials & 179 & 8.38 & 279 & 7.96 \\
Metal industry & 168 & 7.86 & 261 & 7.45 \\
Electrical engineering & 194 & 9.08 & 314 & 8.96 \\
Machine construction & 182 & 8.52 & 279 & 7.96 \\
Vehicle construction & 92 & 4.31 & 168 & 4.79 \\
Transportation & 133 & 6.22 & 239 & 6.82 \\
Media services & 101 & 4.73 & 175 & 4.99 \\
IT and other information services & 169 & 7.91 & 259 & 7.39 \\
Financial and insurance activities & 97 & 4.54 & 211 & 6.02 \\
Real estate activities & 81 & 3.79 & 123 & 3.51 \\
Business consultancy and advertising & 76 & 3.56 & 135 & 3.85 \\
Technical services & 142 & 6.64 & 233 & 6.65 \\
Other business services & 95 & 4.45 & 153 & 4.37 \\
\hline obs. & 2137 & 100 & 3504 & 100 \\
\hline \hline
\end{tabular}

Data source: ZEW ICT survey 2010.

Table 8: Average firm characteristics

\begin{tabular}{lccccc}
\hline & \multicolumn{5}{c}{ Manufacturing sector $(\mathrm{N}=1243)$} \\
& Mean & SD & Median & Min & Max \\
\hline no. employees & 185.26 & 941.01 & 40 & 5 & 25000 \\
sales in million Euro & 43.17 & 258.04 & 4.5 & 0.08 & 7000 \\
labour productivity in million Euro & 0.17 & 0.21 & 0.12 & 0.02 & 2.85 \\
\% exporters & 0.69 & 0.46 & 1 & 0 & 1 \\
\% with foreign affiliate & 0.17 & 0.37 & 0 & 0 & 1 \\
\% highly skilled employees & 0.15 & 0.17 & 0.10 & 0 & 1 \\
\% of firms with product innovation & 0.63 & 0.48 & 1 & 0 & 1 \\
\% of firms with process innovation & 0.62 & 0.49 & 1 & 0 & 1 \\
\% of firms with works council & 0.34 & 0.47 & 0 & 0 & 1 \\
workplace organization indicator & 2.34 & 1.30 & 2 & 0 & 5 \\
\hline \hline & & Service & sector $(\mathrm{N}=894)$ & \\
& Mean & SD & Median & Min & Max \\
\hline no. employees & 242.35 & 1349.50 & 25 & 5 & 30000 \\
sales in million Euro & 59.15 & 617.47 & 2.55 & 0.09 & 15000 \\
labour productivity in million Euro & 0.16 & 0.24 & 0.10 & 0.02 & 2.86 \\
\% exporters & 0.29 & 0.45 & 0 & 0 & 1 \\
\% with foreign affiliate & 0.10 & 0.31 & 0 & 0 & 1 \\
\% highly skilled employees & 0.32 & 0.31 & 0.20 & 0 & 1 \\
\% of firms with product innovation & 0.49 & 0.50 & 0 & 0 & 1 \\
\% of firms with process innovation & 0.63 & 0.48 & 1 & 0 & 1 \\
\% of firms with works council & 0.28 & 0.45 & 0 & 0 & 1 \\
workplace organization indicator & 2.40 & 1.28 & 2 & 0 & 5 \\
\hline
\end{tabular}

Data source: ZEW ICT survey 2010. 
Table 9: Average firm characteristics by global sourcing status

\begin{tabular}{|c|c|c|c|c|}
\hline \multirow[t]{3}{*}{ Variables } & \multicolumn{2}{|c|}{ global sourcing firms } & \multicolumn{2}{|c|}{ non-global sourcing firms } \\
\hline & \multicolumn{4}{|c|}{ Manufacturing sector $(\mathrm{N}=1243)$} \\
\hline & Mean & $\mathrm{SD}$ & Mean & SD \\
\hline no. employees & 252.18 & 1188.33 & 87.13 & 313.63 \\
\hline sales in million Euro & 59.63 & 321.91 & 19.03 & 106.70 \\
\hline labour productivity in million Euro & 0.20 & 0.22 & 0.14 & 0.18 \\
\hline$\%$ exporters & 0.84 & 0.37 & 0.47 & 0.50 \\
\hline$\%$ with foreign affiliate & 0.23 & 0.42 & 0.07 & 0.26 \\
\hline \% highly skilled employees & 0.16 & 0.17 & 0.12 & 0.17 \\
\hline$\%$ of firms with product innovation & 0.70 & 0.46 & 0.52 & 0.50 \\
\hline$\%$ of firms with process innovation & 0.67 & 0.47 & 0.54 & 0.50 \\
\hline$\%$ of firms with works council & 0.42 & 0.49 & 0.22 & 0.41 \\
\hline \multirow[t]{2}{*}{ workplace organization indicator } & 2.58 & 1.28 & 1.99 & 1.26 \\
\hline & \multicolumn{4}{|c|}{ Service sector $(\mathrm{N}=894)$} \\
\hline no. employees & 289.38 & 1043.33 & 230.49 & 1416.67 \\
\hline sales in million Euro & 53.95 & 234.56 & 60.47 & 680.95 \\
\hline labour productivity in million Euro & 0.19 & 0.33 & 0.15 & 0.21 \\
\hline$\%$ exporters & 0.59 & 0.49 & 0.21 & 0.41 \\
\hline$\%$ with foreign affiliate & 0.22 & 0.42 & 0.07 & 0.26 \\
\hline \% highly skilled employees & 0.36 & 0.32 & 0.31 & 0.30 \\
\hline$\%$ of firms with product innovation & 0.69 & 0.46 & 0.44 & 0.50 \\
\hline$\%$ of firms with process innovation & 0.69 & 0.46 & 0.61 & 0.49 \\
\hline$\%$ of firms with works council & 0.34 & 0.48 & 0.26 & 0.44 \\
\hline workplace organization indicator & 2.78 & 1.22 & 2.31 & 1.28 \\
\hline
\end{tabular}

Data source: ZEW ICT survey 2010. 
Table 10: Global sourcing probability and ICT - Robustness checks

\begin{tabular}{|c|c|c|c|c|c|c|}
\hline & \multicolumn{6}{|c|}{ Manufacturing sector } \\
\hline & $(1)$ & $(2)$ & (3) & $(4)$ & (5) & (6) \\
\hline & $\begin{array}{l}3 \text {-digit industry } \\
\text { controls }\end{array}$ & tertiles & $\begin{array}{c}\text { IT } \\
\text { outsourcing }\end{array}$ & $\begin{array}{c}\text { E-commerce \& } \\
\text { software indicator }\end{array}$ & $\begin{array}{l}\text { ICT dummy } \\
\text { variables }\end{array}$ & $\begin{array}{c}\text { ICT usage } \\
\text { intensity indicator }\end{array}$ \\
\hline E-commerce indicator & $\begin{array}{c}0.013 \\
(0.016)\end{array}$ & $\begin{array}{c}0.015 \\
(0.015)\end{array}$ & $\begin{array}{c}0.014 \\
(0.017)\end{array}$ & & & \\
\hline Internet ordering & & & & & $\begin{array}{c}0.015 \\
(0.030)\end{array}$ & \\
\hline B2B e-commerce & & & & & $\begin{array}{c}0.029 \\
(0.029)\end{array}$ & \\
\hline B2C e-commerce & & & & & $\begin{array}{l}-0.005 \\
(0.037)\end{array}$ & \\
\hline $\begin{array}{l}\text { E-commerce usage } \\
\text { intensity }\end{array}$ & & & & & & $\begin{array}{c}0.012 \\
(0.015)\end{array}$ \\
\hline Software indicator & $\begin{array}{l}-0.002 \\
(0.012)\end{array}$ & $\begin{array}{l}-0.000 \\
(0.012)\end{array}$ & $\begin{array}{l}-0.004 \\
(0.013)\end{array}$ & & & \\
\hline ERP software & & & & & $\begin{array}{c}0.010 \\
(0.034)\end{array}$ & \\
\hline CDMS software & & & & & $\begin{array}{l}-0.005 \\
(0.028)\end{array}$ & \\
\hline SCM software & & & & & $\begin{array}{l}0.029 \\
(0.030)\end{array}$ & \\
\hline CRM software & & & & & $\begin{array}{l}-0.036 \\
(0.031)\end{array}$ & \\
\hline ICT usage intensity & & & & & & $\begin{array}{c}0.004 \\
(0.017)\end{array}$ \\
\hline $\begin{array}{l}\text { E-commerce \& } \\
\text { software indicator }\end{array}$ & & & & $\begin{array}{c}0.006 \\
(0.009)\end{array}$ & & \\
\hline \% empl. working with PC & $\begin{array}{c}0.011 \\
(0.078)\end{array}$ & $\begin{array}{c}0.031 \\
(0.075)\end{array}$ & $\begin{array}{c}0.045 \\
(0.079)\end{array}$ & $\begin{array}{c}0.023 \\
(0.075)\end{array}$ & $\begin{array}{c}0.027 \\
(0.076)\end{array}$ & $\begin{array}{c}0.024 \\
(0.075)\end{array}$ \\
\hline$\%$ empl. with Internet access & $\begin{array}{c}0.139^{* * *} \\
(0.052)\end{array}$ & $\begin{array}{c}0.150^{* * *} \\
(0.051)\end{array}$ & $\begin{array}{c}0.141^{* * *} \\
(0.054)\end{array}$ & $\begin{array}{c}0.145^{* * *} \\
(0.051)\end{array}$ & $\begin{array}{r}0.147^{* * *} \\
(0.051)\end{array}$ & $\begin{array}{c}0.145^{* * *} \\
(0.051)\end{array}$ \\
\hline $\ln ($ employment $)$ & $\begin{array}{l}0.032^{* *} \\
(0.015)\end{array}$ & $\begin{array}{c}0.020 \\
(0.014)\end{array}$ & $\begin{array}{c}0.011 \\
(0.015)\end{array}$ & $\begin{array}{c}0.019 \\
(0.014)\end{array}$ & $\begin{array}{c}0.020 \\
(0.014)\end{array}$ & $\begin{array}{l}0.020 \\
(0.014)\end{array}$ \\
\hline $\ln$ (labour productivity) & $\begin{array}{c}0.061^{* * *} \\
(0.022)\end{array}$ & & $\begin{array}{l}0.048^{* *} \\
(0.021)\end{array}$ & $\begin{array}{l}0.047^{* *} \\
(0.020)\end{array}$ & $\begin{array}{l}0.047^{* *} \\
(0.020)\end{array}$ & $\begin{array}{l}0.047^{* *} \\
(0.020)\end{array}$ \\
\hline 2. productivity tertile & & $\begin{array}{c}0.032 \\
(0.030)\end{array}$ & & & & \\
\hline 3. productivity tertile & & $\begin{array}{l}0.082^{* *} \\
(0.036)\end{array}$ & & & & \\
\hline export activity & $\begin{array}{c}0.240^{* * *} \\
(0.030)\end{array}$ & $\begin{array}{c}0.267^{* * *} \\
(0.027)\end{array}$ & $\begin{array}{c}0.275^{* * *} \\
(0.029)\end{array}$ & $\begin{array}{c}0.263^{* * *} \\
(0.027)\end{array}$ & $\begin{array}{c}0.264^{* * *} \\
(0.027)\end{array}$ & $\begin{array}{c}0.264^{* * *} \\
(0.027)\end{array}$ \\
\hline foreign location & $\begin{array}{c}0.029 \\
(0.039)\end{array}$ & $\begin{array}{c}0.061 \\
(0.040)\end{array}$ & $\begin{array}{c}0.060 \\
(0.041)\end{array}$ & $\begin{array}{c}0.062 \\
(0.040)\end{array}$ & $\begin{array}{c}0.061 \\
(0.040)\end{array}$ & $\begin{array}{c}0.061 \\
(0.040)\end{array}$ \\
\hline \% highly skilled empl. & $\begin{array}{l}-0.105 \\
(0.096)\end{array}$ & $\begin{array}{l}-0.081 \\
(0.094)\end{array}$ & $\begin{array}{l}-0.112 \\
(0.097)\end{array}$ & $\begin{array}{l}-0.081 \\
(0.093)\end{array}$ & $\begin{array}{l}-0.082 \\
(0.094)\end{array}$ & $\begin{array}{c}-0.082 \\
(0.093)\end{array}$ \\
\hline product innovation & $\begin{array}{c}0.042 \\
(0.028)\end{array}$ & $\begin{array}{c}0.049^{*} \\
(0.027)\end{array}$ & $\begin{array}{l}0.053^{*} \\
(0.029)\end{array}$ & $\begin{array}{l}0.051^{*} \\
(0.027)\end{array}$ & $\begin{array}{c}0.052^{*} \\
(0.027)\end{array}$ & $\begin{array}{l}0.050^{*} \\
(0.027)\end{array}$ \\
\hline process innovation & $\begin{array}{l}0.047^{*} \\
(0.027)\end{array}$ & $\begin{array}{l}0.051^{*} \\
(0.027)\end{array}$ & $\begin{array}{c}0.045 \\
(0.028)\end{array}$ & $\begin{array}{l}0.047^{*} \\
(0.027)\end{array}$ & $\begin{array}{l}0.048^{*} \\
(0.027)\end{array}$ & $\begin{array}{l}0.047^{*} \\
(0.027)\end{array}$ \\
\hline works council & $\begin{array}{c}-0.018 \\
(0.036)\end{array}$ & $\begin{array}{c}0.013 \\
(0.036)\end{array}$ & $\begin{array}{c}0.025 \\
(0.038)\end{array}$ & $\begin{array}{c}0.010 \\
(0.035)\end{array}$ & $\begin{array}{c}0.007 \\
(0.036)\end{array}$ & $\begin{array}{c}0.011 \\
(0.035)\end{array}$ \\
\hline workplace organization & $\begin{array}{l}0.026^{* *} \\
(0.012)\end{array}$ & $\begin{array}{l}0.027^{* *} \\
(0.012)\end{array}$ & $\begin{array}{c}0.018 \\
(0.012)\end{array}$ & $\begin{array}{l}0.025^{* *} \\
(0.012)\end{array}$ & $\begin{array}{l}0.025^{* *} \\
(0.012)\end{array}$ & $\begin{array}{l}0.025^{* *} \\
(0.012)\end{array}$ \\
\hline IT outsourcing & & & $\begin{array}{c}0.063 \\
(0.042)\end{array}$ & & & \\
\hline sector and location dummies & yes & yes & yes & yes & yes & yes \\
\hline number of observations & 1202 & 1243 & 1087 & 1243 & 1243 & 1243 \\
\hline Pseudo- $R^{2}$ & 0.2140 & 0.1710 & 0.1773 & 0.1713 & 0.1731 & 0.1715 \\
\hline
\end{tabular}

Significance levels: $\quad *: 10 \% \quad * *: 5 \% \quad * * *: 1 \%$. Robust standard errors in parentheses. Sector dummy variables include a full set of two-digit industry dummy variables, location defines a dummy variable if the firm is located in a new member state, i.e. in former East Germany. Moreover, all regressions control for multi-plant affiliation. 
Table 11: Global sourcing probability and ICT - Robustness checks

\begin{tabular}{|c|c|c|c|c|c|c|c|}
\hline & $(1)$ & $(2)$ & $(3)$ & $\begin{array}{l}\text { Service sector } \\
(4)\end{array}$ & $(5)$ & $(6)$ & $(7)$ \\
\hline & $\begin{array}{l}\text { 3-digit industry } \\
\text { controls }\end{array}$ & tertiles & $\begin{array}{c}\text { IT } \\
\text { outsourcing }\end{array}$ & $\begin{array}{c}\text { E-commerce \& } \\
\text { software indicator }\end{array}$ & $\begin{array}{l}\text { ICT dummy } \\
\text { variables }\end{array}$ & $\begin{array}{l}\mathrm{B} 2 \mathrm{~B} \& \mathrm{~B} 2 \mathrm{C} \\
\text { indicator }\end{array}$ & $\begin{array}{c}\text { ICT usage } \\
\text { intensity indicator }\end{array}$ \\
\hline E-commerce indicator & $\begin{array}{c}0.062^{* * *} \\
(0.016)\end{array}$ & $\begin{array}{c}0.054^{* * *} \\
(0.015)\end{array}$ & $\begin{array}{c}0.065^{* * *} \\
(0.015)\end{array}$ & & & & \\
\hline Internet ordering & & & & & $\begin{array}{c}0.122^{* * *} \\
(0.038)\end{array}$ & $\begin{array}{c}0.121^{* * *} \\
(0.038)\end{array}$ & \\
\hline B2B e-commerce & & & & & $\begin{array}{c}0.030 \\
(0.027)\end{array}$ & & \\
\hline B2C e-commerce & & & & & $\begin{array}{c}0.039 \\
(0.034)\end{array}$ & & \\
\hline B2B \& B2C indicator & & & & & & $\begin{array}{l}0.034^{*} \\
(0.018)\end{array}$ & \\
\hline E-commerce usage intensity & & & & & & & $\begin{array}{c}0.047^{* * *} \\
(0.012)\end{array}$ \\
\hline Software indicator & $\begin{array}{c}0.008 \\
(0.014)\end{array}$ & $\begin{array}{c}0.008 \\
(0.013)\end{array}$ & $\begin{array}{c}0.003 \\
(0.013)\end{array}$ & & & $\begin{array}{c}0.008 \\
(0.013)\end{array}$ & \\
\hline ERP software & & & & & $\begin{array}{c}0.025 \\
(0.032)\end{array}$ & & \\
\hline CDMS software & & & & & $\begin{array}{l}-0.012 \\
(0.030)\end{array}$ & & \\
\hline SCM software & & & & & $\begin{array}{c}0.008 \\
(0.030)\end{array}$ & & \\
\hline CRM software & & & & & $\begin{array}{l}0.015 \\
(0.029)\end{array}$ & & \\
\hline ICT usage intensity & & & & & & & $\begin{array}{c}0.009 \\
(0.017)\end{array}$ \\
\hline E-commerce \& software indicator & & & & $\begin{array}{c}0.028^{* * *} \\
(0.009)\end{array}$ & & & \\
\hline \% empl. working with PC & $\begin{array}{l}-0.033 \\
(0.063)\end{array}$ & $\begin{array}{l}-0.029 \\
(0.055)\end{array}$ & $\begin{array}{l}-0.031 \\
(0.059)\end{array}$ & $\begin{array}{l}-0.036 \\
(0.056)\end{array}$ & $\begin{array}{l}-0.020 \\
(0.055)\end{array}$ & $\begin{array}{l}-0.024 \\
(0.055)\end{array}$ & $\begin{array}{l}-0.036 \\
(0.055)\end{array}$ \\
\hline$\%$ empl. with Internet access & $\begin{array}{l}0.060 \\
(0.063)\end{array}$ & $\begin{array}{c}0.054 \\
(0.060)\end{array}$ & $\begin{array}{c}0.028 \\
(0.065)\end{array}$ & $\begin{array}{l}0.048 \\
(0.061)\end{array}$ & $\begin{array}{c}0.051 \\
(0.061)\end{array}$ & $\begin{array}{c}0.053 \\
(0.060)\end{array}$ & $\begin{array}{c}0.050 \\
(0.060)\end{array}$ \\
\hline $\ln ($ employment $)$ & $\begin{array}{c}0.002 \\
(0.015)\end{array}$ & $\begin{array}{l}-0.001 \\
(0.014)\end{array}$ & $\begin{array}{c}0.005 \\
(0.014)\end{array}$ & $\begin{array}{l}-0.003 \\
(0.013)\end{array}$ & $\begin{array}{c}0.001 \\
(0.014)\end{array}$ & $\begin{array}{c}0.002 \\
(0.014)\end{array}$ & $\begin{array}{c}0.002 \\
(0.013)\end{array}$ \\
\hline $\ln$ (labour productivity) & $\begin{array}{l}0.043^{* *} \\
(0.019)\end{array}$ & & $\begin{array}{c}0.054^{* * *} \\
(0.018)\end{array}$ & $\begin{array}{l}0.039^{* *} \\
(0.018)\end{array}$ & $\begin{array}{l}0.039^{* *} \\
(0.018)\end{array}$ & $\begin{array}{l}0.040^{* *} \\
(0.018)\end{array}$ & $\begin{array}{l}0.037^{* *} \\
(0.018)\end{array}$ \\
\hline 2. productivity tertile & & $\begin{array}{c}0.026 \\
(0.030)\end{array}$ & & & & & \\
\hline 3. productivity tertile & & $\begin{array}{l}0.088^{* *} \\
(0.036)\end{array}$ & & & & & \\
\hline export activity & $\begin{array}{c}0.179^{* * *} \\
(0.028)\end{array}$ & $\begin{array}{c}0.180^{* * *} \\
(0.025)\end{array}$ & $\begin{array}{c}0.168^{* * *} \\
(0.026)\end{array}$ & $\begin{array}{c}0.178^{* * *} \\
(0.025)\end{array}$ & $\begin{array}{c}0.181^{* * *} \\
(0.025)\end{array}$ & $\begin{array}{c}0.180^{* * *} \\
(0.025)\end{array}$ & $\begin{array}{c}0.178^{* * *} \\
(0.025)\end{array}$ \\
\hline foreign location & $\begin{array}{c}0.056 \\
(0.044)\end{array}$ & $\begin{array}{c}0.056 \\
(0.039)\end{array}$ & $\begin{array}{l}0.081^{*} \\
(0.042)\end{array}$ & $\begin{array}{c}0.055 \\
(0.039)\end{array}$ & $\begin{array}{c}0.054 \\
(0.039)\end{array}$ & $\begin{array}{c}0.054 \\
(0.039)\end{array}$ & $\begin{array}{c}0.057 \\
(0.039)\end{array}$ \\
\hline$\%$ highly skilled empl. & $\begin{array}{c}-0.044 \\
(0.064)\end{array}$ & $\begin{array}{l}-0.032 \\
(0.054)\end{array}$ & $\begin{array}{l}-0.030 \\
(0.057)\end{array}$ & $\begin{array}{l}-0.038 \\
(0.054)\end{array}$ & $\begin{array}{l}-0.033 \\
(0.054)\end{array}$ & $\begin{array}{l}-0.032 \\
(0.054)\end{array}$ & $\begin{array}{l}-0.037 \\
(0.054)\end{array}$ \\
\hline product innovation & $\begin{array}{c}0.052 \\
(0.032)\end{array}$ & $\begin{array}{l}0.061^{* *} \\
(0.029)\end{array}$ & $\begin{array}{c}0.079^{* * * *} \\
(0.030)\end{array}$ & $\begin{array}{l}0.060^{* *} \\
(0.029)\end{array}$ & $\begin{array}{l}0.063^{* *} \\
(0.029)\end{array}$ & $\begin{array}{l}0.061^{* *} \\
(0.029)\end{array}$ & $\begin{array}{l}0.058^{* *} \\
(0.029)\end{array}$ \\
\hline process innovation & $\begin{array}{c}-0.014 \\
(0.030)\end{array}$ & $\begin{array}{l}-0.011 \\
(0.028)\end{array}$ & $\begin{array}{c}-0.020 \\
(0.029)\end{array}$ & $\begin{array}{l}-0.016 \\
(0.028)\end{array}$ & $\begin{array}{l}-0.010 \\
(0.028)\end{array}$ & $\begin{array}{l}-0.010 \\
(0.028)\end{array}$ & $\begin{array}{c}-0.010 \\
(0.028)\end{array}$ \\
\hline works council & $\begin{array}{c}0.012 \\
(0.041)\end{array}$ & $\begin{array}{c}0.017 \\
(0.037)\end{array}$ & $\begin{array}{c}-0.006 \\
(0.038)\end{array}$ & $\begin{array}{c}0.009 \\
(0.037)\end{array}$ & $\begin{array}{c}0.010 \\
(0.037)\end{array}$ & $\begin{array}{c}0.010 \\
(0.037)\end{array}$ & $\begin{array}{c}0.013 \\
(0.037)\end{array}$ \\
\hline workplace organization & $\begin{array}{l}-0.002 \\
(0.012)\end{array}$ & $\begin{array}{c}0.003 \\
(0.012)\end{array}$ & $\begin{array}{l}-0.003 \\
(0.012)\end{array}$ & $\begin{array}{c}0.003 \\
(0.012)\end{array}$ & $\begin{array}{c}0.002 \\
(0.012)\end{array}$ & $\begin{array}{c}0.003 \\
(0.012)\end{array}$ & $\begin{array}{c}0.003 \\
(0.012)\end{array}$ \\
\hline IT-outsourcing & & & $\begin{array}{c}0.062 \\
(0.038)\end{array}$ & & & & \\
\hline sector and location dummies & yes & yes & yes & yes & yes & yes & yes \\
\hline number of observations & 809 & 894 & 781 & 894 & 894 & 894 & 894 \\
\hline Pseudo- $R^{2}$ & 0.1952 & 0.1765 & 0.2113 & 0.1708 & 0.1808 & 0.1799 & 0.1761 \\
\hline
\end{tabular}


Table 12: Global sourcing probability and ICT - For different subsamples of firms

\begin{tabular}{|c|c|c|c|c|c|c|c|c|c|c|c|}
\hline & \multicolumn{11}{|c|}{ Manufacturing sector } \\
\hline & \multirow[b]{3}{*}{$\begin{array}{l}\text { Across firm } \\
\text { boundaries }\end{array}$} & $(2)$ & $(3)$ & $(4)$ & $(5)$ & $(6)$ & (7) & $(8)$ & $(9)$ & $(10)$ & $(11)$ \\
\hline & & \multirow[b]{2}{*}{ Exporters } & \multirow[b]{2}{*}{$\begin{array}{l}\text { Internet } \\
\text { ordering }\end{array}$} & \multicolumn{4}{|c|}{ Higher upstream industry diversity } & \multicolumn{4}{|c|}{ Lower upstream industry diversity } \\
\hline & & & & All firms & $\begin{array}{l}\text { Across firm } \\
\text { boundaries }\end{array}$ & Exporters & $\begin{array}{l}\text { Internet } \\
\text { ordering }\end{array}$ & All firms & $\begin{array}{l}\text { Across firm } \\
\text { boundaries }\end{array}$ & Exporters & $\begin{array}{l}\text { Internet } \\
\text { ordering }\end{array}$ \\
\hline \multirow[t]{2}{*}{ E-commerce indicator } & 0.016 & 0.002 & 0.008 & $0.061^{* *}$ & $0.058^{*}$ & 0.050 & 0.060 & -0.003 & 0.000 & -0.019 & -0.013 \\
\hline & $(0.017)$ & $(0.018)$ & $(0.021)$ & $(0.029)$ & $(0.032)$ & $(0.034)$ & $(0.039)$ & $(0.018)$ & $(0.020)$ & $(0.021)$ & $(0.025)$ \\
\hline \multirow[t]{2}{*}{ Software indicator } & -0.001 & -0.007 & 0.004 & -0.007 & -0.022 & -0.010 & 0.009 & 0.005 & 0.012 & -0.006 & 0.006 \\
\hline & $(0.013)$ & $(0.014)$ & $(0.014)$ & $(0.023)$ & $(0.025)$ & $(0.026)$ & $(0.026)$ & $(0.014)$ & $(0.016)$ & $(0.017)$ & $(0.017)$ \\
\hline \% empl. working with $\mathrm{PC}$ & $(0.082)$ & $(0.094)$ & $(0.084)$ & $(0.142)$ & $(0.163)$ & $(0.164)$ & $(0.154)$ & $(0.088)$ & $(0.095)$ & $(0.113)$ & $(0.101)$ \\
\hline \multirow[t]{2}{*}{$\%$ empl. with Internet access } & $0.146^{* * *}$ & $0.149^{* *}$ & $0.095^{*}$ & -0.004 & 0.009 & -0.011 & -0.026 & $0.199^{* * *}$ & $0.188^{* * *}$ & $0.228^{* * *}$ & $0.134^{*}$ \\
\hline & $(0.055)$ & $(0.067)$ & $(0.057)$ & $(0.095)$ & $(0.105)$ & $(0.109)$ & $(0.101)$ & $(0.060)$ & $(0.063)$ & $(0.084)$ & $(0.069)$ \\
\hline \multirow[t]{2}{*}{$\ln ($ employment $)$} & $0.028^{*}$ & $0.032^{*}$ & 0.020 & 0.021 & 0.051 & 0.010 & 0.009 & 0.017 & 0.014 & $0.047^{* *}$ & 0.021 \\
\hline & $(0.016)$ & $(0.017)$ & $(0.016)$ & $(0.025)$ & $(0.031)$ & $(0.027)$ & $(0.028)$ & $(0.016)$ & $(0.019)$ & $(0.020)$ & $(0.019)$ \\
\hline \multirow[t]{2}{*}{$\ln$ (labour productivity) } & $0.058^{* *}$ & 0.010 & 0.026 & $0.087^{* *}$ & $0.100^{* *}$ & 0.062 & 0.063 & 0.026 & 0.041 & -0.032 & 0.003 \\
\hline & $(0.022)$ & $(0.024)$ & $(0.024)$ & $(0.036)$ & $(0.041)$ & $(0.042)$ & $(0.042)$ & $(0.024)$ & $(0.026)$ & $(0.029)$ & $(0.028)$ \\
\hline \multirow[t]{2}{*}{ export activity } & $0.256^{* * *}$ & & $0.273^{* * *}$ & $0.289^{* * *}$ & $0.281^{\text {*** }}$ & & $0.304^{* * *}$ & $0.255^{* * *}$ & $0.250^{* * *}$ & & $0.266^{* * *}$ \\
\hline & $(0.029)$ & & $(0.030)$ & $(0.053)$ & $(0.056)$ & & $(0.057)$ & $(0.031)$ & $(0.033)$ & & $(0.036)$ \\
\hline foreign location & & $(0.040)$ & $(0.044)$ & $(0.066)$ & & $(0.067)$ & $(0.070)$ & $(0.049)$ & & $(0.049)$ & $(0.055)$ \\
\hline \multirow[t]{2}{*}{$\%$ highly skilled empl. } & -0.098 & -0.173 & -0.015 & -0.097 & -0.036 & $-0.329^{*}$ & 0.023 & -0.038 & -0.105 & -0.018 & -0.002 \\
\hline & $(0.104)$ & $(0.114)$ & $(0.108)$ & $(0.160)$ & $(0.182)$ & $(0.178)$ & $(0.180)$ & $(0.112)$ & $(0.123)$ & $(0.145)$ & $(0.132)$ \\
\hline \multirow[t]{2}{*}{ product innovation } & $0.057^{*}$ & 0.037 & 0.028 & 0.050 & 0.051 & 0.056 & 0.014 & 0.047 & 0.056 & 0.022 & 0.034 \\
\hline & $(0.030)$ & $(0.033)$ & $(0.031)$ & $(0.051)$ & $(0.057)$ & $(0.058)$ & $(0.055)$ & $(0.032)$ & $(0.036)$ & $(0.040)$ & $(0.037)$ \\
\hline \multirow[t]{2}{*}{ process innovation } & 0.045 & $0.069^{* *}$ & 0.044 & $0.109^{* *}$ & 0.075 & $0.144^{* * *}$ & $0.116^{* *}$ & 0.012 & 0.023 & 0.017 & 0.008 \\
\hline & $(0.030)$ & $(0.032)$ & $(0.030)$ & $(0.048)$ & $(0.055)$ & $(0.054)$ & $(0.054)$ & $(0.031)$ & $(0.035)$ & $(0.040)$ & $(0.036)$ \\
\hline \multirow[t]{2}{*}{ works council } & 0.004 & -0.023 & 0.026 & -0.023 & -0.064 & -0.032 & 0.011 & 0.034 & 0.037 & -0.008 & 0.039 \\
\hline & $(0.041)$ & $(0.039)$ & $(0.040)$ & $(0.062)$ & $(0.076)$ & $(0.066)$ & $(0.070)$ & $(0.042)$ & $(0.048)$ & $(0.048)$ & $(0.048)$ \\
\hline \multirow[t]{2}{*}{ workplace organization } & $0.036^{* * *}$ & $0.023^{*}$ & $0.031^{* *}$ & 0.009 & 0.026 & 0.006 & 0.023 & $0.037^{* * *}$ & $0.044^{* * *}$ & $0.035^{* *}$ & $0.035^{* *}$ \\
\hline & $(0.013)$ & $(0.014)$ & $(0.013)$ & $(0.020)$ & $(0.022)$ & $(0.024)$ & $(0.023)$ & $(0.014)$ & $(0.015)$ & $(0.017)$ & $(0.016)$ \\
\hline sector and location dummies & yes & yes & yes & yes & yes & yes & yes & yes & yes & yes & yes \\
\hline number of observations & 1035 & 859 & 965 & 378 & 304 & 296 & 299 & 865 & 731 & 563 & 666 \\
\hline Pseudo- $R^{2}$ & 0.1701 & 0.0536 & 0.1723 & 0.1626 & 0.1663 & 0.0800 & 0.1790 & 0.1912 & 0.1844 & 0.0744 & 0.1823 \\
\hline
\end{tabular}

Table 13: Global sourcing probability and ICT - For different subsamples of firms

\begin{tabular}{|c|c|c|c|c|c|c|c|c|c|c|}
\hline & \multicolumn{10}{|c|}{ Service sector } \\
\hline & $(1)$ & $(2)$ & $(3)$ & $(4)$ & $(5)$ & (6) & (7) & (8) & $(9)$ & $(10)$ \\
\hline & & & & Higl & er upstream in & ndustry dive & sity & Lower ups & tream indust & $y$ diversity \\
\hline & $\begin{array}{l}\text { Across firm } \\
\text { boundaries }\end{array}$ & Exporters & $\begin{array}{l}\text { Internet } \\
\text { ordering }\end{array}$ & All firms & $\begin{array}{l}\text { Across firm } \\
\text { boundaries }\end{array}$ & Exporters & $\begin{array}{l}\text { Internet } \\
\text { ordering }\end{array}$ & All firms & $\begin{array}{l}\text { Across firm } \\
\text { boundaries }\end{array}$ & $\begin{array}{l}\text { Internet } \\
\text { ordering }\end{array}$ \\
\hline E-commerce indicator & $0.053^{* * *}$ & $0.096^{* * *}$ & $0.042^{* *}$ & $0.069^{* * *}$ & $0.058^{* * *}$ & $0.122^{* * *}$ & $0.053^{*}$ & $0.045^{* *}$ & $0.055^{* * *}$ & 0.044 \\
\hline & $(0.015)$ & $(0.036)$ & $(0.021)$ & $(0.021)$ & $(0.021)$ & $(0.044)$ & $(0.029)$ & $(0.020)$ & $(0.020)$ & $(0.028)$ \\
\hline Software indicator & 0.004 & 0.017 & 0.009 & 0.016 & 0.014 & 0.024 & 0.019 & 0.000 & -0.009 & -0.007 \\
\hline & $(0.013)$ & $(0.031)$ & $(0.015)$ & $(0.018)$ & $(0.018)$ & $(0.036)$ & $(0.019)$ & $(0.018)$ & $(0.019)$ & $(0.023)$ \\
\hline$\%$ empl. working with PC & -0.038 & 0.130 & -0.013 & -0.127 & -0.117 & -0.039 & $-0.148^{*}$ & 0.069 & 0.042 & $0.152^{*}$ \\
\hline & $(0.054)$ & $(0.140)$ & $(0.064)$ & $(0.080)$ & $(0.078)$ & $(0.173)$ & $(0.088)$ & $(0.072)$ & $(0.069)$ & $(0.088)$ \\
\hline$\%$ empl. with Internet access & 0.035 & 0.115 & 0.054 & 0.120 & 0.120 & 0.150 & 0.116 & 0.010 & -0.016 & -0.002 \\
\hline & $(0.059)$ & $(0.153)$ & $(0.071)$ & $(0.101)$ & $(0.100)$ & $(0.205)$ & $(0.110)$ & $(0.071)$ & $(0.069)$ & $(0.088)$ \\
\hline $\ln ($ employment $)$ & 0.004 & 0.009 & -0.004 & 0.007 & -0.002 & 0.028 & -0.001 & 0.005 & 0.021 & 0.002 \\
\hline & $(0.014)$ & $(0.034)$ & $(0.016)$ & $(0.020)$ & $(0.021)$ & $(0.040)$ & $(0.022)$ & $(0.018)$ & $(0.018)$ & $(0.021)$ \\
\hline $\ln$ (labour productivity) & $0.032^{*}$ & $0.187^{* * *}$ & 0.030 & $0.081^{* * *}$ & $0.063^{* *}$ & $0.180^{* * *}$ & $0.084^{* * *}$ & 0.009 & 0.008 & -0.012 \\
\hline & $(0.019)$ & $(0.050)$ & $(0.022)$ & $(0.027)$ & $(0.029)$ & $(0.058)$ & $(0.029)$ & $(0.022)$ & $(0.022)$ & $(0.027)$ \\
\hline export activity & $0.165^{* * *}$ & & $0.201^{* * *}$ & $0.168^{* * *}$ & $0.157^{* * *}$ & & $0.190^{* * *}$ & $0.197^{* * *}$ & $0.188^{* * *}$ & $0.218^{* * *}$ \\
\hline & $(0.026)$ & & $(0.029)$ & $(0.034)$ & $(0.034)$ & & $(0.038)$ & $(0.038)$ & $(0.038)$ & $(0.046)$ \\
\hline foreign location & & $0.135^{*}$ & $0.094^{* *}$ & 0.080 & & $0.171^{*}$ & $0.124^{* *}$ & 0.006 & 0.000 & 0.020 \\
\hline & & $(0.077)$ & $(0.046)$ & $(0.051)$ & & $(0.088)$ & $(0.058)$ & $(0.063)$ & & $(0.080)$ \\
\hline$\%$ highly skilled empl. & -0.000 & $-0.313^{* * *}$ & -0.041 & -0.033 & -0.014 & $-0.247^{*}$ & -0.034 & 0.021 & 0.070 & 0.028 \\
\hline & $(0.057)$ & $(0.119)$ & $(0.064)$ & $(0.069)$ & $(0.073)$ & $(0.129)$ & $(0.078)$ & $(0.095)$ & $(0.094)$ & $(0.118)$ \\
\hline product innovation & $0.065^{* *}$ & 0.063 & $0.076^{* *}$ & 0.065 & 0.072 & 0.087 & $0.099^{* *}$ & 0.049 & 0.052 & 0.037 \\
\hline & $(0.029)$ & $(0.073)$ & $(0.033)$ & $(0.045)$ & $(0.045)$ & $(0.091)$ & $(0.050)$ & $(0.037)$ & $(0.036)$ & $(0.044)$ \\
\hline process innovation & -0.015 & -0.023 & -0.005 & 0.012 & 0.009 & 0.015 & 0.025 & -0.049 & -0.053 & -0.054 \\
\hline & $(0.028)$ & $(0.073)$ & $(0.033)$ & $(0.039)$ & $(0.039)$ & $(0.077)$ & $(0.044)$ & $(0.041)$ & $(0.041)$ & $(0.050)$ \\
\hline works council & 0.017 & -0.145 & 0.028 & -0.017 & 0.044 & $-0.266^{* *}$ & -0.012 & 0.018 & -0.015 & 0.046 \\
\hline & $(0.039)$ & $(0.093)$ & $(0.044)$ & $(0.058)$ & $(0.062)$ & $(0.108)$ & $(0.065)$ & $(0.046)$ & $(0.048)$ & $(0.057)$ \\
\hline workplace organization & 0.002 & 0.017 & -0.000 & -0.005 & -0.008 & 0.024 & -0.011 & 0.011 & 0.011 & 0.015 \\
\hline & $(0.012)$ & $(0.029)$ & $(0.014)$ & $(0.016)$ & $(0.018)$ & $(0.034)$ & $(0.019)$ & $(0.016)$ & $(0.016)$ & $(0.021)$ \\
\hline sector and location dummies & yes & yes & yes & yes & yes & yes & yes & yes & yes & yes \\
\hline number of observations & 801 & 257 & 724 & 482 & 418 & 182 & 405 & 412 & 383 & 319 \\
\hline Pseudo- $R^{2}$ & 0.1536 & 0.1248 & 0.1636 & 0.1765 & 0.1451 & 0.1425 & 0.1805 & 0.1981 & 0.1979 & 0.1876 \\
\hline
\end{tabular}


Table 14: Global sourcing probability and ICT - For different sets of SMEs

\begin{tabular}{|c|c|c|c|c|c|c|}
\hline & \multicolumn{6}{|c|}{ Manufacturing sector } \\
\hline & $(1)$ & $(2)$ & (3) & (4) & $(5)$ & (6) \\
\hline & $\begin{array}{c}\text { All } \\
\text { SMEs }\end{array}$ & $\begin{array}{l}\text { Across firm } \\
\text { boundaries }\end{array}$ & Exporters & $\begin{array}{l}\text { Internet } \\
\text { ordering }\end{array}$ & $\begin{array}{l}\text { Higher upstream } \\
\text { industry diversity }\end{array}$ & $\begin{array}{l}\text { Lower upstream } \\
\text { industry diversity }\end{array}$ \\
\hline E-commerce indicator & $\begin{array}{c}0.021 \\
(0.017)\end{array}$ & $\begin{array}{c}0.020 \\
(0.018)\end{array}$ & $\begin{array}{c}0.007 \\
(0.021)\end{array}$ & $\begin{array}{c}0.013 \\
(0.023)\end{array}$ & $\begin{array}{l}0.077^{* *} \\
(0.031)\end{array}$ & $\begin{array}{c}0.001 \\
(0.019)\end{array}$ \\
\hline Software indicator & $\begin{array}{l}-0.005 \\
(0.013)\end{array}$ & $\begin{array}{l}-0.001 \\
(0.014)\end{array}$ & $\begin{array}{l}-0.012 \\
(0.016)\end{array}$ & $\begin{array}{l}0.001 \\
(0.015)\end{array}$ & $\begin{array}{l}-0.017 \\
(0.024)\end{array}$ & $\begin{array}{c}0.004 \\
(0.015)\end{array}$ \\
\hline \% empl. working with PC & $\begin{array}{l}0.040 \\
(0.080)\end{array}$ & $\begin{array}{l}0.080 \\
(0.085)\end{array}$ & $\begin{array}{l}0.025 \\
(0.104)\end{array}$ & $\begin{array}{l}0.061 \\
(0.090)\end{array}$ & $\begin{array}{l}0.168 \\
(0.151)\end{array}$ & $\begin{array}{l}0.006 \\
(0.094)\end{array}$ \\
\hline$\%$ empl. with Internet access & $\begin{array}{r}0.145^{* * *} \\
(0.055)\end{array}$ & $\begin{array}{c}0.152^{* * *} \\
(0.057)\end{array}$ & $\begin{array}{l}0.150^{* *} \\
(0.074)\end{array}$ & $\begin{array}{c}0.083 \\
(0.062)\end{array}$ & $\begin{array}{l}-0.058 \\
(0.102)\end{array}$ & $\begin{array}{c}0.208^{* * *} \\
(0.063)\end{array}$ \\
\hline $\ln ($ employment $)$ & $\begin{array}{l}0.018 \\
(0.017)\end{array}$ & $\begin{array}{c}0.021 \\
(0.019)\end{array}$ & $\begin{array}{c}0.032 \\
(0.021)\end{array}$ & $\begin{array}{l}0.021 \\
(0.020)\end{array}$ & $\begin{array}{l}0.030 \\
(0.032)\end{array}$ & $\begin{array}{l}0.009 \\
(0.020)\end{array}$ \\
\hline $\ln$ (labour productivity) & $\begin{array}{c}0.060^{* * *} \\
(0.021)\end{array}$ & $\begin{array}{c}0.065^{* * *} \\
(0.023)\end{array}$ & $\begin{array}{c}0.027 \\
(0.027)\end{array}$ & $\begin{array}{c}0.038 \\
(0.026)\end{array}$ & $\begin{array}{l}0.093^{* *} \\
(0.038)\end{array}$ & $\begin{array}{l}0.046^{*} \\
(0.025)\end{array}$ \\
\hline export activity & $\begin{array}{c}0.267^{* * *} \\
(0.028)\end{array}$ & $\begin{array}{c}0.268^{* * *} \\
(0.030)\end{array}$ & & $\begin{array}{c}0.277^{* * *} \\
(0.032)\end{array}$ & $\begin{array}{c}0.305^{* * *} \\
(0.055)\end{array}$ & $\begin{array}{c}0.255^{* * *} \\
(0.033)\end{array}$ \\
\hline foreign location & $\begin{array}{l}0.092^{*} \\
(0.048)\end{array}$ & & $\begin{array}{l}0.104^{* *} \\
(0.049)\end{array}$ & $\begin{array}{l}0.091^{*} \\
(0.054)\end{array}$ & $\begin{array}{c}0.129 \\
(0.081)\end{array}$ & $\begin{array}{c}0.079 \\
(0.058)\end{array}$ \\
\hline$\%$ highly skilled empl. & $\begin{array}{l}-0.053 \\
(0.098)\end{array}$ & $\begin{array}{l}-0.105 \\
(0.106)\end{array}$ & $\begin{array}{l}-0.133 \\
(0.124)\end{array}$ & $\begin{array}{c}0.061 \\
(0.113)\end{array}$ & $\begin{array}{l}-0.008 \\
(0.166)\end{array}$ & $\begin{array}{l}-0.048 \\
(0.116)\end{array}$ \\
\hline product innovation & $\begin{array}{l}0.057^{*} \\
(0.029)\end{array}$ & $\begin{array}{l}0.058^{*} \\
(0.031)\end{array}$ & $\begin{array}{c}0.048 \\
(0.037)\end{array}$ & $\begin{array}{c}0.031 \\
(0.034)\end{array}$ & $\begin{array}{l}0.029 \\
(0.054)\end{array}$ & $\begin{array}{l}0.064^{*} \\
(0.034)\end{array}$ \\
\hline process innovation & $\begin{array}{c}0.039 \\
(0.028)\end{array}$ & $\begin{array}{c}0.040 \\
(0.030)\end{array}$ & $\begin{array}{c}0.062^{*} \\
(0.035)\end{array}$ & $\begin{array}{c}0.042 \\
(0.032)\end{array}$ & $\begin{array}{c}0.082 \\
(0.051)\end{array}$ & $\begin{array}{c}0.011 \\
(0.033)\end{array}$ \\
\hline works council & $\begin{array}{l}0.015 \\
(0.038)\end{array}$ & $\begin{array}{l}0.007 \\
(0.043)\end{array}$ & $\begin{array}{l}-0.010 \\
(0.043)\end{array}$ & $\begin{array}{c}0.027 \\
(0.044)\end{array}$ & $\begin{array}{l}-0.036 \\
(0.068)\end{array}$ & $\begin{array}{l}0.041 \\
(0.045)\end{array}$ \\
\hline workplace organization & $\begin{array}{c}0.033^{* * *} \\
(0.012)\end{array}$ & $\begin{array}{c}0.039^{* * *} \\
(0.013)\end{array}$ & $\begin{array}{l}0.033^{* *} \\
(0.015)\end{array}$ & $\begin{array}{c}0.039^{* * *} \\
(0.014)\end{array}$ & $\begin{array}{c}0.021 \\
(0.022)\end{array}$ & $\begin{array}{c}0.043^{* * *} \\
(0.015)\end{array}$ \\
\hline sector and location dummies & yes & yes & yes & yes & yes & yes \\
\hline number of observations & 1096 & 963 & 725 & 839 & 330 & 766 \\
\hline Pseudo- $R^{2}$ & 0.1736 & 0.1657 & 0.0526 & 0.1741 & 0.1786 & 0.1895 \\
\hline
\end{tabular}


Table 15: Global sourcing probability and ICT - For different sets of SMEs

\begin{tabular}{|c|c|c|c|c|c|c|}
\hline & $(1)$ & $(2)$ & $(3)$ & $\begin{array}{l}\text { Service sector } \\
(4)\end{array}$ & $(5)$ & $(6)$ \\
\hline & $\begin{array}{l}\text { ICT \& } \\
\text { controls }\end{array}$ & $\begin{array}{l}\text { Across firm } \\
\text { boundaries }\end{array}$ & Exporters & $\begin{array}{l}\text { Only firms with } \\
\text { Internet ordering }\end{array}$ & $\begin{array}{l}\text { Higher upstream } \\
\text { industry diversity }\end{array}$ & $\begin{array}{l}\text { Lower upstream } \\
\text { industry diversity }\end{array}$ \\
\hline E-commerce indicator & $\begin{array}{c}0.055^{* * *} \\
(0.015)\end{array}$ & $\begin{array}{c}0.051^{* * *} \\
(0.015)\end{array}$ & $\begin{array}{c}0.132^{* * *} \\
(0.038)\end{array}$ & $\begin{array}{l}0.045^{* *} \\
(0.022)\end{array}$ & $\begin{array}{c}0.066^{* * *} \\
(0.022)\end{array}$ & $\begin{array}{l}0.049^{* *} \\
(0.020)\end{array}$ \\
\hline Software indicator & $\begin{array}{c}0.006 \\
(0.012)\end{array}$ & $\begin{array}{c}0.009 \\
(0.012)\end{array}$ & $\begin{array}{c}0.015 \\
(0.034)\end{array}$ & $\begin{array}{c}0.009 \\
(0.015)\end{array}$ & $\begin{array}{c}0.010 \\
(0.017)\end{array}$ & $\begin{array}{l}-0.001 \\
(0.019)\end{array}$ \\
\hline$\%$ empl. working with $\mathrm{PC}$ & $\begin{array}{l}-0.048 \\
(0.057)\end{array}$ & $\begin{array}{l}-0.054 \\
(0.057)\end{array}$ & $\begin{array}{c}0.137 \\
(0.147)\end{array}$ & $\begin{array}{l}-0.022 \\
(0.068)\end{array}$ & $\begin{array}{c}-0.155^{* *} \\
(0.078)\end{array}$ & $\begin{array}{c}0.072 \\
(0.080)\end{array}$ \\
\hline$\%$ empl. with Internet access & $\begin{array}{c}0.043 \\
(0.062)\end{array}$ & $\begin{array}{c}0.029 \\
(0.062)\end{array}$ & $\begin{array}{c}0.065 \\
(0.162)\end{array}$ & $\begin{array}{l}0.045 \\
(0.075)\end{array}$ & $\begin{array}{c}0.083 \\
(0.104)\end{array}$ & $\begin{array}{l}0.010 \\
(0.076)\end{array}$ \\
\hline $\ln ($ employment $)$ & $\begin{array}{l}-0.005 \\
(0.017)\end{array}$ & $\begin{array}{l}-0.006 \\
(0.017)\end{array}$ & $\begin{array}{l}-0.070 \\
(0.044)\end{array}$ & $\begin{array}{l}-0.015 \\
(0.020)\end{array}$ & $\begin{array}{l}-0.022 \\
(0.026)\end{array}$ & $\begin{array}{c}0.022 \\
(0.023)\end{array}$ \\
\hline $\ln$ (labour productivity) & $\begin{array}{c}0.053^{* * *} \\
(0.019)\end{array}$ & $\begin{array}{c}0.050^{* * *} \\
(0.019)\end{array}$ & $\begin{array}{c}0.204^{* * *} \\
(0.057)\end{array}$ & $\begin{array}{l}0.040^{*} \\
(0.023)\end{array}$ & $\begin{array}{c}0.092^{* * *} \\
(0.028)\end{array}$ & $\begin{array}{c}0.022 \\
(0.022)\end{array}$ \\
\hline export activity & $\begin{array}{c}0.175^{* * *} \\
(0.025)\end{array}$ & $\begin{array}{c}0.159^{* * *} \\
(0.026)\end{array}$ & & $\begin{array}{c}0.203^{* * *} \\
(0.030)\end{array}$ & $\begin{array}{c}0.159^{* * *} \\
(0.033)\end{array}$ & $\begin{array}{c}0.202^{* * *} \\
(0.039)\end{array}$ \\
\hline foreign location & $\begin{array}{l}0.083^{*} \\
(0.043)\end{array}$ & & $\begin{array}{l}0.185^{* *} \\
(0.085)\end{array}$ & $\begin{array}{l}0.121^{* *} \\
(0.052)\end{array}$ & $\begin{array}{l}0.109^{*} \\
(0.056)\end{array}$ & $\begin{array}{c}0.032 \\
(0.073)\end{array}$ \\
\hline \% highly skilled empl. & $\begin{array}{l}-0.035 \\
(0.055)\end{array}$ & $\begin{array}{l}-0.010 \\
(0.056)\end{array}$ & $\begin{array}{l}-0.243^{*} \\
(0.124)\end{array}$ & $\begin{array}{l}-0.060 \\
(0.066)\end{array}$ & $\begin{array}{l}-0.022 \\
(0.070)\end{array}$ & $\begin{array}{l}0.006 \\
(0.100)\end{array}$ \\
\hline product innovation & $\begin{array}{l}0.068^{* *} \\
(0.030)\end{array}$ & $\begin{array}{l}0.077^{* *} \\
(0.030)\end{array}$ & $\begin{array}{c}0.107 \\
(0.076)\end{array}$ & $\begin{array}{l}0.077^{* *} \\
(0.035)\end{array}$ & $\begin{array}{l}0.084^{*} \\
(0.046)\end{array}$ & $\begin{array}{l}0.045 \\
(0.038)\end{array}$ \\
\hline process innovation & $\begin{array}{l}-0.011 \\
(0.029)\end{array}$ & $\begin{array}{l}-0.025 \\
(0.029)\end{array}$ & $\begin{array}{l}-0.011 \\
(0.075)\end{array}$ & $\begin{array}{l}-0.006 \\
(0.034)\end{array}$ & $\begin{array}{c}0.008 \\
(0.039)\end{array}$ & $\begin{array}{l}-0.038 \\
(0.041)\end{array}$ \\
\hline works council & $\begin{array}{c}0.009 \\
(0.038)\end{array}$ & $\begin{array}{c}0.005 \\
(0.041)\end{array}$ & $\begin{array}{l}-0.093 \\
(0.095)\end{array}$ & $\begin{array}{c}0.028 \\
(0.046)\end{array}$ & $\begin{array}{c}0.007 \\
(0.063)\end{array}$ & $\begin{array}{c}-0.010 \\
(0.046)\end{array}$ \\
\hline workplace organization & $\begin{array}{c}0.001 \\
(0.012)\end{array}$ & $\begin{array}{c}0.002 \\
(0.012)\end{array}$ & $\begin{array}{c}0.013 \\
(0.031)\end{array}$ & $\begin{array}{l}-0.000 \\
(0.014)\end{array}$ & $\begin{array}{l}-0.004 \\
(0.017)\end{array}$ & $\begin{array}{c}0.006 \\
(0.017)\end{array}$ \\
\hline sector and location dummies & yes & yes & yes & yes & yes & yes \\
\hline number of observations & 784 & 724 & 217 & 630 & 425 & 359 \\
\hline Pseudo- $R^{2}$ & 0.1958 & 0.1715 & 0.1662 & 0.1814 & 0.1985 & 0.2240 \\
\hline
\end{tabular}


Table 16: Industry classification

\begin{tabular}{|c|c|}
\hline Explanation & WZ 2008 \\
\hline $\begin{array}{l}\text { Consumer goods } \\
\text { manufacture of food products, beverages and tobacco } \\
\text { manufacture of textiles, textile products, leather and leather products, shoes } \\
\text { manufacture of wood and wood products } \\
\text { manufacturing of pulp, paper and paper products } \\
\text { manufacturing of furniture, other commodities }\end{array}$ & $\begin{array}{l}10-12 \\
13-15 \\
16 \\
17 \\
31-32\end{array}$ \\
\hline $\begin{array}{l}\text { Chemical and pharmaceutical industry } \\
\text { manufacture of chemicals and chemical products } \\
\text { manufacture of pharmaceutical products }\end{array}$ & $\begin{array}{l}20 \\
21\end{array}$ \\
\hline $\begin{array}{l}\text { Other raw materials } \\
\text { manufacture of rubber and plastic products } \\
\text { manufacture of glass, glass products, ceramic; stones and noble earths }\end{array}$ & $\begin{array}{l}22 \\
23\end{array}$ \\
\hline $\begin{array}{l}\text { Metal industry } \\
\text { metal production and processing } \\
\text { manufacture of fabricated metal products (except machinery and equipment) }\end{array}$ & $\begin{array}{l}24 \\
25\end{array}$ \\
\hline $\begin{array}{l}\text { Electrical engineering } \\
\text { manufacture of data processing equipment, electronic and optic products } \\
\text { manufacture of electrical machinery and apparatus }\end{array}$ & $\begin{array}{l}26 \\
27\end{array}$ \\
\hline $\begin{array}{l}\text { Machine construction } \\
\text { manufacture of machinery } \\
\text { reparation and installation of machinery and equipments }\end{array}$ & $\begin{array}{l}28 \\
33\end{array}$ \\
\hline $\begin{array}{l}\text { Vehicle construction } \\
\text { manufacturing of motor vehicle and further vehicle parts } \\
\text { manufacturing of other transport equipment }\end{array}$ & $\begin{array}{l}29 \\
30\end{array}$ \\
\hline $\begin{array}{l}\text { Transportation } \\
\text { land transport, transport via pipeline } \\
\text { water transport } \\
\text { air transport } \\
\text { warehousing and further transport services } \\
\text { post and courier activities } \\
\text { supporting and auxiliary transport activities; activities of travel agencies }\end{array}$ & $\begin{array}{l}49 \\
50 \\
51 \\
52 \\
53 \\
79\end{array}$ \\
\hline $\begin{array}{l}\text { Media services } \\
\text { manufacture of publishing and printing } \\
\text { publishing } \\
\text { manufacture, rental and distribution of movies and television programmes; } \\
\text { cinemas and distribution of music; broadcasting }\end{array}$ & $\begin{array}{c}18 \\
58 \\
59-60\end{array}$ \\
\hline $\begin{array}{l}\text { IT and other information services } \\
\text { telecommunications } \\
\text { information technology services }\end{array}$ & $\begin{array}{c}61 \\
62-63\end{array}$ \\
\hline $\begin{array}{l}\text { Financial and insurance activities } \\
\text { financial intermediation } \\
\text { insurance activities } \\
\text { services related to financial and insurance activities }\end{array}$ & $\begin{array}{l}64 \\
65 \\
66\end{array}$ \\
\hline $\begin{array}{l}\text { Real estate activities } \\
\text { property and housing } \\
\text { renting of movable products }\end{array}$ & $\begin{array}{l}68 \\
77\end{array}$ \\
\hline $\begin{array}{l}\text { Business consultancy and advertising } \\
\text { legal advice, accounting and auditing activities; tax consultancy; } \\
\text { business and management consultancy } \\
\text { advertising and market research }\end{array}$ & $\begin{array}{c}69-70 \\
73\end{array}$ \\
\hline $\begin{array}{l}\text { Technical services } \\
\text { architectural and engineering activities and related technical consultancy; } \\
\text { technical testing and analysis } \\
\text { research and development }\end{array}$ & $\begin{array}{l}71 \\
72\end{array}$ \\
\hline $\begin{array}{l}\text { Other business-related services } \\
\text { other self-employed, scientific and technical activities } \\
\text { labour recruitment and provision of personnel } \\
\text { investigation and security services; industrial cleaning; } \\
\text { miscellaneous business activities n.e.c. }\end{array}$ & $\begin{array}{c}74 \\
78 \\
80-82\end{array}$ \\
\hline
\end{tabular}

Source: ZEW 2010. WZ 2008 is the abbreviation for the German classification of industries; it corresponds to the NACE industry classification. 


\section{A.2 Upstream industry diversity measure based on input-output tables}

In order to compute upstream industry diversity at the industry level, I use information from the German input-output (IO) tables from 2009, published in 2013 (article number:

2180200097005). The German IO tables include three relevant tables for the inputs, measured in costs, from one industry by another: 1. Inputs from domestic production and imports, 2. Imported inputs only, 3. Domestic inputs only. In total, there are 73 industries at the two-digit level (Classification of the industries 2008 (WZ 2008)) to potentially source from but none of the industries sources from all potential industries. I use the variation in the number of industries a certain industry sources inputs from in order to compute a measure for input industry diversity. For the main measure used in the paper, I consider the variation in the number of industries for domestic input sourcing as well as for import sourcing

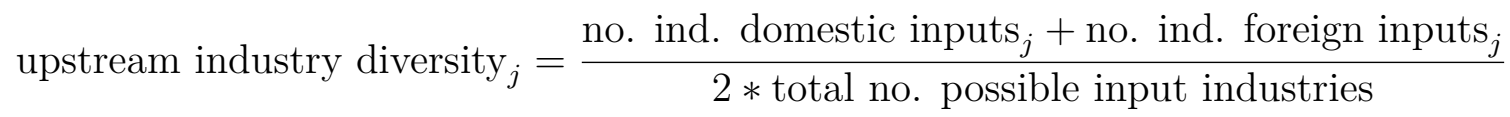

This formula is identical to the one in 4.2.3. Since the industry classification used in this paper is broader than the classification at the two-digit industry level in the IO tables, I compute the upstream industry diversity ratio for each two-digit industry in the IO tables and then I take the average of those values aggregated to the industry composition used in this paper (see Table 16). Table 17 shows the upstream industry diversity ratios for each broad industry in the ICT survey and the categorization into higher and lower upstream industry diversity based on the median value. Higher values indicate that an industry sources inputs from more different industries, domestically and from abroad.

Table 17: Upstream industry diversity

\begin{tabular}{|c|c|c|}
\hline Industry & $\begin{array}{c}\text { Upstream industry } \\
\text { diversity ratio }\end{array}$ & Classification \\
\hline \multicolumn{3}{|l|}{ Manufacturing sector } \\
\hline Consumer goods & 0.65 & low \\
\hline Chemical and pharmaceutical industry & 0.71 & high \\
\hline Other raw materials & 0.62 & low \\
\hline Metal industry & 0.66 & low \\
\hline Electrical engineering & 0.66 & low \\
\hline Machine construction & 0.71 & high \\
\hline Vehicle construction & 0.69 & high \\
\hline Median & 0.66 & \\
\hline Standard deviation & 0.031 & \\
\hline \multicolumn{3}{|l|}{ Service Sector } \\
\hline Transportation & 0.44 & Tow \\
\hline Media services & 0.53 & low \\
\hline IT and other information services & 0.54 & high \\
\hline Financial and insurance activities & 0.50 & low \\
\hline Real estate activities & 0.49 & low \\
\hline Business consultancy and advertising & 0.57 & high \\
\hline Technical services & 0.55 & high \\
\hline Other business services & 0.58 & high \\
\hline Median & 0.53 & \\
\hline Standard deviation & 0.047 & \\
\hline
\end{tabular}

Data source: ZEW ICT survey 2010. 
The values for upstream industry diversity reflect that all manufacturing industries source from more other industries than all service industries. Moreover, according to the standard deviation the heterogeneity is larger in service than in manufacturing industries. This comparison between the manufacturing and service sector is plausible given that supply chains are on average less complex in service industries than in manufacturing, at least to the extent with how many different industries service industries trade upstream.

The same categorization of industries into higher and lower upstream industry diversity is obtained when in the numerator of the formula for upstream industry diversity either the number of industries with positive domestic inputs or the corresponding number of import industries or the number of industries, either domestic or foreign, are considered. The denominator is then only one time the number of possible industries, i.e. 73. The IO tables show that the central difference in the number of industries with positive inputs between domestic industries and foreign industries is that the number of domestic input industries is larger than the number of foreign input industries for manufacturing as well as for service industries. Consequently, the upstream industry diversity ratios are larger for domestic inputs than for imported inputs (not reported). 